\title{
SENJSKA ŠTEDIONICA SENJ (1873. - 1948.)
}

\author{
Siniša Lajnert \\ Hrvatski državni arhiv \\ Marulićev trg 21 \\ HR 10000 Zagreb \\ slajnert@arhiv.hr
}

\author{
UDK: 336.72/.73(497.5Senj) “19” \\ 930.253(497.5Senj) “19” \\ Izvorni znanstveni članak \\ 13.06.2019.
}

Autor u članku s aspekta povijesti institucija obrađuje ustroj, poslovanje i likvidaciju Senjske štedionice Senj od 1873., kada je štedionica osnovana, pa sve do 1948., kada je završena njezina likvidacija. Poslove štedionice obavljali su glavna skupština dioničara, ravnateljstvo i nadzorni odbor. Usprkos velikim ekonomskim krizama te dvama svjetskim ratovima, Senjska štedionica izbjegla je sudbinu većine novčarskih zavoda koji su poslovali s gubitkom. Bila je jedan od rijetkih zavoda koji nikada nije imao nikakve zaštitne mjere niti mu je ikada bio postavljen povjerenik. Ravnateljstvo štedionice uvijek je polazilo od stajališta da prvenstveno treba očuvati zavod, u čemu se i uspjelo. Štedionica je upornim nastojanjem njezina ravnateljstva i činovništva te poslovnih prijatelja prebrodila sve krize, uglavnom s lakoćom, makar i uz skromni dobitak. Ravnateljstvo je prilagođavalo svoj rad prilikama i vjerno svojim principima, kako bi štedionica što bolje poslužila poslovnom svijetu te uspješno sačuvala stečeno povjerenje poslovnih prijatelja.

Neposredno nakon završetka 2. svjetskog rata rad štedionice posve je stao. S obzirom na to da nije postojao niti jedan od uvjeta za daljnji uspješan rad Senjske štedionice i s obzirom na plansku likvidaciju privatnih novčarskih zavoda, u socijalističkoj Jugoslaviji je već 1945. godine određena likvidacija zavoda, koja je završena 1948. godine.

Ključne riječi: Senjska štedionica Senj, novčarski zavod, štedioničko poslovanje, dioničari, bilanca, likvidacija, 1873. - 1948.

\section{Uvod}

U članku su s aspekta povijesti institucija prikazani rezultati istraživanja ustroja te poslovanja i likvidacije Senjske štedionice Senj (1873. - 1948.). Članak se temelji prvenstveno na proučavanju sačuvanoga arhivskog gradiva koje se nalazi u Hrvatskom državnom arhivu (HDA). Arhivski fondovi korišteni u ovome radu su: HR-HDA-79. Zemaljska vlada. Odjel za unutarnje posloveZagreb (1869. - 1921.), HR-HDA-152. Savska financijska direkcija-Zagreb (1929. - 1939.), HR-HDA-215. Ministarstvo državne riznice Nezavisne Države Hrvatske-Zagreb (1941. - 1945.), HR-HDA-313. Zemaljska uprava narodnih 
dobara Narodne Republike Hrvatske (Zemaljska uprava narodnih dobara Federalne Hrvatske 1945. - 1946., Zemaljska uprava narodnih dobara NRH 1946. - 1954.)-Zagreb (1945. - 1954.) i HR-HDA-620. Služba likvidacije starih poslova centrale Narodne banke Jugoslavije u Zagrebu (1946. - 1972.). Treba napomenuti da se u Hrvatskom državnom arhivu nalazi i zaseban arhivski fond HR-HDA-564. Senjska štedionica - Senj (1873. - 1948.) ${ }^{1}$, čije arhivsko gradivo nije korišteno u pisanju ovoga članka. Naime, fond se sastoji od svega pet knjiga koje nisu od većega značaja za ovaj rad, i to: 1. Dnevnik knjigovodstva XVIII, 1943. - 1947.; 2. Glavna knjiga VII, 1921. - 1947.; 3. Knjiga dionica I (1-22.500) 1923. - 1947.; 4. Knjiga uložaka XIII, 1932. - 1945. i 5. Knjiga saldo conti XII, 1942. - 1947. Osim analize arhivskih fondova, u radu su obrađeni i izvodi iz trgovačkih registara nadležnih sudova, kao i drugi predmetni akti i propisi objavljeni u službenim glasilima, službeni shematizmi te predmetna znanstvena i stručna literatura.

O Senjskoj štedionici u razdoblju od 1873. do 1948. dosad se samo periferno istraživalo, uglavnom u sklopu istraživanja o politici ${ }^{2}$ i gospodarstvu te političarima i gospodarstvenicima senjskoga područja. Tako je u tom kontekstu objavljen veći broj članaka, kojima glavna tema nije bila Senjska štedionica, ali se ona ipak ukratko i usputno spominje. Nekoliko značajnih podataka o samoj štedionici objavio je 2017. Ivan Brlić u svojoj knjizi Lička $i$ senjska građanska društva 1835. - 1945. Značajan izvor podataka predstavljaju i tadašnje dnevne tiskovine, koje, osim Narodnih novina, nisu obrađene u ovom članku. Za nadopunu ovdje iznesenih podataka upućujem zainteresirane na taj izvor podataka.

Osim Senjske štedionice, u Senju su u promatranom razdoblju postojali još neki novčarski zavodi, i to Činovnička štedna i predujamna zadruga za Hrvatsko Primorje (osnovana 1880.) ${ }^{3}$, Hrvatska pučka štedionica kao udruga u

\section{${ }^{1}$ J. KOLANOVIĆ (ur.), 1984, 90.}

${ }^{2}$ Senjska štedionica postala je stožerom pravaške ideje u Senju. Vidi: A. GLAVIČIĆ, 1994, 246.

${ }^{3}$ Hrvatski kompas, financijalni ljetopis za 1913./14. o poslovanju privrednih institucija: banaka, štedionica, zadruga, industrialnih, parobrodarskih $i$ inih trgovačkih poduzeća u Hrvatskoj, Slavoniji, Dalmaciji, Istri, Kranjskoj, Koruškoj, Štajerskoj, Bosni i Hercegovini, uz dodatak nekih novčanih zavoda u Ugarskoj, Srbiji i Crnoj Gori, 1913, 487. Godine 1917. spominje se pod nazivom Činovnička štedna i predujmovna zadruga u Senju (osnovana 1880). Vidi: Izvještaj Upravnog odbora i kr. podžupana županije Ličko-krbavske od 1. siječnja do 31. prosinca 1917., 1919, 172. Neki autori spominju je pod nazivom: Činovnička štedionica i predujmovna zadruga za Hrvatsko primorje. Vidi: I. BRLIĆ, 2017, 326. 
Senju (osnovana 1910.) ${ }^{4}$, podružnica u Senju Prve hrvatske štedionice (osnovana 1911.) ${ }^{5}$ te podružnica u Senju Hrvatske centralne banke d.d. (osnovana 1921.) ${ }^{6}$, koji zbog nedovoljno relevantnih podataka nisu obrađeni u ovom članku. ${ }^{7}$

\section{Djelovanje Senjske štedionice Senj u Austro-Ugarskoj Monarhiji \\ Osnutak Senjske štedionice Senj i upisi u trgovački registar}

Otpisom Kraljevskog ugarskog ministarstva za poljodjelstvo, obrt i trgovinu (Földmivelés-ipar-és kereskedelemugyi minisztérium/ Kön. ung. Ministerium für Ackerbau, Industrie und Handel) u Budimpešti br. 13.097 od 7. prosinca 1872. dozvoljeno je osnivanje Senjske štedionice u Kraljevskom i slobodnom pomorskom gradu Senju. Povodom toga, koncesionari Senjske štedionice objavili su 10. veljače 1873. oglas u dnevnom tisku da će se glavna skupština dioničara održati 22 . veljače 1873 . u 10 sati u prostorijama štedionice. ${ }^{8}$

Kao što je rečeno, 22. veljače 1873. u Senju je održana svečana konstituirajuća glavna skupština Senjske štedionice. Na skupštini je jedan od koncesionara, odvjetnik Vaso Pauković ${ }^{9}$, naglasio da svi veći trgovački gradovi

${ }^{4}$ Hrvatski kompas, financijalni ljetopis za 1913./14. o poslovanju privrednih institucija: banaka, štedionica, zadruga, industrialnih, parobrodarskih i inih trgovačkih poduzeća u Hrvatskoj, Slavoniji, Dalmaciji, Istri, Kranjskoj, Koruškoj, Štajerskoj, Bosni i Hercegovini, uz dodatak nekih novčanih zavoda u Ugarskoj, Srbiji i Crnoj Gori, 1913, 488.

${ }^{5}$ Kraljevski kotarski kao trgovački sud u Senju upisao je 16. lipnja 1911. podružnicu u Senju Prve hrvatske štedionice. Vidi: Upisi tvrdka, Narodne novine, br. 147, 28. lipnja 1911, 11. Sudbeni stol kao trgovački sud u Senju upisao je 8. kolovoza 1942. u trgovačkom registru Prvu hrvatsku štedionicu, podružnicu Senj. Vidi: Upisi, Narodne novine. Službeni list Nezavisne Države Hrvatske, br. 219, 29. rujna 1942., 4.

${ }^{6}$ Kr. kotarski kao trgovački sud u Senju upisao je 29. svibnja 1921. u trgovački registar Hrvatsku centralnu banku d.d. na Rijeci, podružnica Senj. Vidi: Upisi tvrdka, Narodne novine, br. 146, 1. srpnja 1921, 5. Dana 9. svibnja 1936. brisana je iz trgovačkog registra suda u Sušaku podružnica u Senju Hrvatske centralne banke d.d. Rijeka, jer je prestala poslovati. Vidi: Brisanja, Narodne novine. Službeni list Kraljevske banske uprave Savske banovine, br. 181, 11. kolovoza 1937., 4.

${ }^{7}$ Osim navedenih senjskih novčarskih zavoda, neki autori spominju još: Činovničku štednu i predujmovnu zadrugu za Hrvatsko Primorje (osnovana 1924) i Zadružnu štedionicu (osnovana 1925) Vidi: I. BRLIĆ, 2017, 326.

${ }^{8}$ Oglas koncesionara Senjske štedionice od 10. veljače 1873, Narodne novine, br. 34, 11. veljače 1873., 4.

${ }^{9}$ Zanimljiva je njegova epizoda dvoboja s pravaškim zastupnikom Pavlovićem oko tobožnje pronevjere novca Senjske štedionice. Naime, kad se raspravljalo o verifikaciji mandata odvjetnika Vase Paukovića, Milan Pavlović ga je optužio da je iz Senjske štedionice ukrao 100 forinti. Teške međusobne optužbe u Saboru završile su dvobojem. Izidor Kršnjavi najprije je bio Paukovićev sekundant, a onda je umjesto njega izašao na dvoboj s Pavlovićem. Dvoboj se odigrao 22. siječnja 1885. u Maksimiru. Iako su pucali iz blizine jedan na drugoga (s 20 koraka), nitko nije u tom dvoboju bio ranjen. Vidi: M. ARTUKOVIĆ, 2006, 231. 
imaju vjeresijske zavode, a skoro da i nema niti jednog grada u zemlji, koji nije imao barem štedionicu. Samo grad Senj do ovoga trenutka nije imao svoju štedionicu. Štedionica je osnovana uz potporu Kraljevske hrvatsko-slavonskodalmatinske zemaljske vlade u Zagrebu. Na skupštini je pročitana ministarska dozvola s pravilima Senjske štedionice te se pristupilo izboru ravnajućega odbora. Početak poslovanja štedionice najavljen je za 1 . ožujka $1873 .{ }^{10}$

Ministarstvo za poljodjelstvo, obrt i trgovinu u Budimpešti poslalo je 16. travnja 1873. Antunu Vakanoviću, banu Kraljevina Hrvatske, Slavonije i Dalmacije u Zagrebu pod br. 5.677 tri potvrđena primjerka konačnih pravila Senjske štedionice. Jedan primjerak pravila zadržao je ban za vlastitu pismohranu, jedan primjerak poslan je pismohrani grada Senja, dok je jedan primjerak poslan ravnateljstvu Senjske štedionice. ${ }^{11}$

Kod Kraljevskog gradskog kao trgovačkog suda u Senju unesena je 8. lipnja 1873. u registar za društvene tvrtke Senjska štedionica. Temelj ove štedionice je rješenje Kr. ug. ministarstva za poljodjelstvo, obrt i trgovinu br. 13.097 od 7 . prosinca 1872. i rješenje Kr. hrv.-slav.-dalm. zemaljske vlade br. 15.891/3.107 od 15. prosinca 1872. te pravila predložena navedenom Ministarstvu pod br. 5.677 od 16. travnja 1873. Svrha štedionice bila je ljudima omogućiti ulaganje njihove štednje uz odgovarajuće kamate te podjeljivanje i uzajmljivanje. Glavnica štedionice ustanovljena je na 50.000 forinti ${ }^{12}$ podijeljenih na 1.000 dionica po 50 forinti glasećih na ime. Od toga je, pismenim očitovanjem upravljujućeg odbora, do tada uplaćeno $50 \%$ odnosno 25.000 forinti. ${ }^{13}$

Nakon što je 16. svibnja 1875. donesen Trgovački zakon Senjska štedionica je upisana u novi registar za društvene tvrtke. Kraljevski kotarski kao trgovački sud

\footnotetext{
${ }^{10}$ Dopis od 28. veljače 1873, Narodne novine, br. 52, 4. ožujka 1873., 2-3.

${ }^{11}$ Hrvatski državni arhiv (HR-HDA) 79. Zemaljska vlada. Odjel za unutarnje poslove Zagreb (1869. - 1921.), sv. 9, kor.br. 276/12455/1872., ur.br. 5908/1873., kut. br. 90.

${ }^{12}$ Uslijed novčanoga ugovora u Beču od 24. siječnja 1857., zbog uređenja novčarstva u cijeloj carevini, Franjo Josip I. izdao je 19. rujna 1857. Cesarski patent br. 167. Navedenim patentom austrijska novčana jedinica zvala se forinta (florenus). Ona se pak dijelila na stotinke, a svaka pak stotinka na desetine. Novac kovan po toj mjeri zvao se "vrednota austrijanska". Vidi: S. LAJNERT, 2015, 142. Svakome novcu, koji se ubuduće kovao, a tako i novcu, koji je kovan s godišnjim brojem 1857., uzimana je za temelj funta, imajući težu od petsto grama. Zakonska zemaljska novčana mjera bila je mjera od četrdeset i pet forinti. Iz jedne funte čistoga srebra kovalo se četrdeset i pet forinti. Vidi: Cesarski patent br. 167 od 19. rujna 1857., kojim se uslied novčanoga ugovora, ddo. u Beču 24. siečnja 1857., proglašenoga u dèř̌avnom zakonskom listu, kom. XXIII., br. 101 od god. 1857., izdaju za svekoliku cesarevinu ustanove za uredjenje novčanstva, Zemaljsko vladni list za kraljevine Hérvatsku i Slavoniju, godina 1857., I. razdiel, II. svezak, br. 167, 1857, 491- 499.

${ }^{13}$ Oglas Gradskog suda u Senju br. 964, Narodne novine, br. 137, 17. lipnja 1873., 4.
} 
u Senju dao je 24. travnja 1876. na znanje da je upis što je objavljen u trgovačkom registru uslijed odluke Kr. gradskog suda u Senju od 8. lipnja 1873., br. 964, i objavljen u Narodnim novinama br. 137 od 17. lipnja 1873., br. 143 od 24. lipnja 1873. i br. 154 od 7. srpnja 1873. prenesen po odredbama Trgovačkog zakona u novi registar za društvene tvrtke uz naziv: Senjska štedionica sa dodatkom: aliter cassa di risparmio Segnana. Svrha društva određena je temeljem pravila od 22. veljače 1873. uz preinake zaključene na glavnoj skupštini štedionice od 12 . ožujka 1876., prema kojima je njezina nadležnost primitak ukamatljivih uloga, predujmovi na vrijednosne papire i zlatni i srebrni novac, zajmovi, mjeničnoodbitni poslovi te odbitkovanje mjenica članova vjeresijskog zbora. Potvrđena je temeljna glavnica od 50.000 forinti razdijeljena na 1.000 dionica po 50 forinti glasećih na ime. ${ }^{14}$

\section{Zakonska regulativa, pravila i obrtna iskaznica Senjske štedionice Senj}

Struktura bankovno-novčarskoga sustava (banke, štedionice, zadruge i osiguravajuća društva) u Hrvatskoj i Slavoniji temeljila se na Trgovačkom zakonu od 16. svibnja 1875. i Obrtnom zakonu od 18. svibnja 1884.

Zakonski članak XXXVII: Trgovački zakon donesen je 16. svibnja 1875. Temeljem navedena zakona, dioničarska društva osnivana su s glavnicom koja je bila unaprijed ustanovljena i sastojala se od određenog broja dionica (cijelih ili podijeljenih) jednake vrijednosti. U takvim društvima vlasnici dionica jamčili su samo do iznosa svojih dionica. Dionička društva smatrana su osnovanima kada im je glavnica bila osigurana, kada su pravila društva bila utvrđena i kada je društvo upisano u registar trgovačkih tvrtki. Sva prava koja su dioničarima pripadala vezano uz poslovanje izvršavao je skup dioničara na glavnoj skupštini. Poslovima dioničarskog društva upravljalo je ravnateljstvo sastavljeno od jedne ili više osoba izabranih među dioničarima ili drugim osobama. Nadzorni odbor je bio tijelo sastavljeno od najmanje tri člana te je kontrolirao vođenje poslovanja društva u svim segmentima. Kontrolirao je godišnje račune i bilancu, kao i prijedloge podjele dobitka. O tim je pitanjima nadzorni odbor podnosio izvješće glavnoj skupštini (skup svih dioničara). Bez toga izvješća glavna skupština nije mogla donijeti valjane zaključke u vezi razdiobe dobitka. Upisi ubilježeni u registre trgovačkih tvrtki trebali su se, ako

${ }^{14}$ Upisi tvrdkah, Narodne novine, br. 102, 4. svibnja 1876, 4. Također, vidi: HR-HDA-215. Ministarstvo državne riznice Nezavisne Države Hrvatske-Zagreb (MDR NDH), dosje Senjske štedionice Senj, Izvadak iz trgovačkog registra Okružnog suda u Sušaku za Senjsku štedionicu u Senju od 19. studenoga 1938., kut. br. 305. 
Zakon nije drugačije odredio, cijelim sadržajem objaviti u centralnom glasniku (központi értesitö), koji je za tu namjenu izdalo Ministarstvo za poljodjelstvo, obrt i trgovinu. Upisi u Kraljevini Hrvatskoj i Slavoniji objavljivani su u Narodnim novinama. Svaki trgovac bio je dužan voditi svezane, list po list rednim brojevima označene te uzicom parafirane knjige, koje su potpuno iskazivale poslovanje i imovinsko stanje. Trgovcima je pri tome dopušteno služiti se bilo kojim načinom knjigovodstva i kojim god živućim jezikom. Svaki trgovac bio je dužan s poslovanjem sastaviti inventar, dakle točno popisanu nepokretnu imovinu, potraživanja i dugovanja, iznos gotovine i ostalu svoju imovinu i naznačiti vrijednost pojedinih svojih dobara, i ujedno sastaviti bilancu, pokazujući razmjer između njegovim aktivnim i pasivnim stanjem. Inventar i bilanca izrađivali su se za svaku godinu. Trgovci su bili slobodni inventar i bilancu upisati u za to predviđenu knjigu ili složiti svaki put posebno. U potonjem slučaju, isprave su se spremale po kronološkom redu. Trgovac je bio dužan arhivirati primljene poslovne listove, a prijepis poslovnih listova, što ih je on poslao - u kopiji ili otisku - zadržati uveden po kronološkom redu u knjigu prijepisa. Temeljem čl. 30. navedenog Zakona, poduzetnici su bili dužni svoje poslovne knjige imati arhivirane barem deset godina, računajući od dana kada je u njih učinjen posljednji upis. Isto je vrijedilo i za trgovačke listove, inventar i bilancu. Uredno vođene poslovne knjige davale su u poslovnim prijeporima u pravilu nepotpun dokaz, koji se mogao nadopuniti prisegom ili kojim drugim dokaznim sredstvom. Ta dokazna moć knjiga trajala je protiv trgovaca deset godina, računajući od dana početka prijepora, a protiv netrgovaca dvije godine. Nakon dokončanja likvidacije javnog trgovačkog društva, knjige i ostali spisi razvrgnutoga društva predavali su se u pohranu nekom članu društva ili trećoj osobi. Ako se članovi nisu mogli sporazumjeti oko izbora skrbnika knjiga i spisa, imenovao ga je na prijedlog neke od stranaka nadležni sudbeni stol. Društveni članovi i njihovi pravni sljednici mogli su i kasnije iza toga razgledavati knjige i spise i služiti se njima. Knjige razvrgnutoga dioničkog društva (čl. 207.) imale su se dati na pohranu na deset godina na mjestu koje je odredio nadležni sudbeni stol. Provođenje ovoga Zakona povjereno je ministru za poljodjelstvo, obrt i trgovinu, a u pravosudnim pitanjima, ministru pravosuđa, dotično u Hrvatskoj i Slavoniji banu kraljevina Hrvatske, Slavonije i Dalmacije. ${ }^{15}$

${ }^{15}$ Sbornik zakonah i naredabah valjanih za kraljevinu Hrvatsku i Slavoniju, godina 1875, br. 79, 1876, 899-1016; Sbornik zakonah i naredabah valjanih za kraljevinu Hrvatsku i Slavoniju, godina 1877, br. 44, 1878, 525-642. Vidi i: S. LAJNERT, 2015, 122-123. 
Zakonski članak XVII: Obrtni zakon donesen je 18. svibnja 1884. Gore spomenuti Trgovački zakon i Obrtni zakon jedan drugoga nisu isključivali. Na području zemalja ugarske krune mogla se svaka punoljetna osoba slobodno i samostalno baviti svim granama obrta, podrazumijevajući i trgovinu. Također, mogao se otvoriti i bankovni obrt. Pravne osobe mogle su se također slobodno baviti obrtom, uz uvjet da postave poslovođu, koji je trebao biti prijavljen obrtnoj oblasti. Za svoje poslovanje obrtnici su dobivali obrtnu iskaznicu, odnosno obrtnu dozvolu, koja je pod određenim brojem upisana u obrtnički registar odnosno obrtni upisnik. ${ }^{16}$

Pravila Senjske štedionice promijenjena su 3. ožujka 1901. na glavnoj skupštini. Potpisali su ih Dragutin Didolić, Šime Štiglić, Ivan Mladineo, Josip Geržanić $^{17}$, Drago Vlahović ${ }^{18}$, Martin Kosina i Konrad Zimpermann. Kr. kotarski kao trgovačko-mjenbeni sud u Senju upisao je 15. studenoga 1901. navedenu promjenu u trgovački registar za društvene tvrtke. Prema tadašnjem razvoju njezinih poslova, svrha joj je bila bavljenje raznovrsnim bankovnim poslovima, a napose: 1. preuzimanje novaca na ukamaćenje uz uložne knjižice i na tekući račun; 2. eskomptiranje i reeskomptiranje mjenica, trgovačkih naputnica te inih vrijednosnih papira; 3. davanje zajma na ručni zalog; 4. davanje vlasnicima nekretnina hipotekarne zajmove, preuzimanje postojećih hipotekarnih tražbina, nabavljanje putem ovrhe hipotekarnim zajmom Senjske štedionice opterećene nekretnine te ove opet dalje prodavati; 5 . kupovanje i prodaja zlatnog i srebrnog novca te svakovrsnih vrijednosnih papira, osobito onih, koji su bili službeno notirani na burzi te koji su nosili stalno opredijeljene kamate. Spekulacija i igranje na burzi bilo je bezuvjetno isključeno. Temeljna dionička glavnica ustanovljena je na uplaćenih 70.000 kruna $^{19}$ (ili 35.000 forinti), koja je razdijeljena na 1.000

${ }^{16}$ Sbornik zakonah i naredabah valjanih za kraljevine Hrvatsku i Slavoniju, godina 1884, br. 31, 1884, 238-277. Vidi i: S. LAJNERT, 2015, 124.

17 Josip Geržanić poznat je i po tome što se prvi usudio i fizički udariti bana Khuena Hederväryja (čuveni "vritnjak"). Opširnije o njemu vidi: M. KOLAR, 1995, 267-292.

${ }^{18}$ O Dragi Vlahoviću vidi: M. KOLAR, 1997, 151-168.

19 Zakonskim člankom XVII. ob ustanovljenju krunske vriednote od 2. kolovoza 1892., na mjesto dotadašnje austrijske vrednote stupa zlatna vrednota kojoj je računska jedinica bila kruna (K). Kruna se dijelila na 100 filira (f). Temeljna težina za kovanje novca bio je kilogram i desetinka istog. Zlatni novac valute kovan je iz smjese koja je sadržavala 900 tisućinki zlata i 100 tisućinki bakra. Na jedan kilogram miješanog zlata otpadale su 2.952 krune, dosljedno tomu, na jedan kilogram finoga zlata 3.280 kruna. Kao primjer usporedbe vrijednosti krune u odnosu na druge valute, navodim podatak da su zadnje godine Prvog svjetskog rata, točnije 21. siječnja 1918., vrijedili sljedeći tečajevi: 100 maraka $=156 \mathrm{~K}$, odnosno $100 \mathrm{~K}=64$ marke 10 pfeniga; 100 bugarskih leva $=126 \mathrm{~K}$, odnosno $100 \mathrm{~K}=79$ leva i 37 stot. Za novčane doznačnice za internirane i ratne zarobljenike vrijedilo je: 100 franaka $=172 \mathrm{~K}$, odnosno $100 \mathrm{~K}=58.14$ franaka. Vidi: S. 
dionica po 70 kruna glasećih na donosioca. Društvene poslove obavljali su: glavna skupština dioničara, ravnateljstvo i nadzorni odbor. ${ }^{20}$

Budući da je temeljem Zakonskog članka XVII: Obrtni zakon dokazala da ima pravo na bavljenje obrtom, 27. ožujka 1901. Gradsko poglavarstvo grada Senja kao obrtna oblast prve molbe izdalo je Senjskoj štedionici pod br. 129/3396-1901. obrtnu iskaznicu. Štedionica je upisana u obrtni upisnik pod br. $6 / \mathrm{E}^{21}$

LAJNERT, 2015, 139. Prije toga, početkom 1. svjetskog rata, točnije 15. siječnja 1915., tečaj marke za preračunavanje kruna u novčanom prometu s Njemačkom iznosio je: 100 maraka=126.75 kruna (1 marka=1K 26.75 fil.). Tečaj franka u prometu sa Švicarskom iznosio je: 100 franaka=112 kruna (1 franak=1K 12 fil.). Vidi: Narodne novine, br. 13, 18. siječnja 1915, 4. Da bi smo shvatili realnu vrijednost krune te je usporedili sa stvarnom vrijednošću kapitala štedionice, spomenimo da su prema podacima Poglavarstva slob. i kr. glavnog grada Zagreba upućenim 4. travnja 1917. Ces. i kr. vojnom zapovjedništvu u Zagrebu cijene tadašnjih živežnih namirnica bile sljedeće: govedina za pečenje 9-14 kruna po kg, stražnji dio govedine 8,80-10 kruna po kg, prednji dio govedine 8-9,60 kruna po kg, pšenično brašno br. $2-0,76$ kruna, pšenično brašno br. $0-1,16$ kruna, pšenično brašno br. 6 - 0,56 kruna, grah 1,60 kruna, krumpir 0,37 kruna, kiseli kupus 0,72 kruna, kisela repa 0,52 kruna, svinjska mast 12 kruna, maslo 16 kruna, češnjak 5 kruna po $\mathrm{kg}$, luk crljenac 1,20-1,60 kruna po kg, paprika 40 kruna, papar 50 kruna, zelenje za juhu 2,60 kruna, ocat 1 kruna po litri. Prema podacima Poglavarstva grada Zagreba upućenim 7. travnja 1917. Intendanciji Ces. i kr. vojnog zapovjedništva u Zagrebu o tadašnjim tržnim cijenama kravljeg i goveđeg mesa, cijene su bile sljedeće: stražnji dio vola 9,20-10 kruna po kg, prednji dio vola 8,409,60 kruna po kg, stražnji dio krave 9,20-9,60 kruna po kg, prednji dio krave 8-8,80 kruna po kg. Već 21. travnja 1917. Poglavarstvo grada Zagreba izvješćuje o višim tržnim cijenama volovskog i kravljeg mesa, i to: stražnji dio vola 10,40-12 kruna po kg, prednji dio vola 9,60-10,20 kruna po kg, stražnji dio krave 9,60-10 kruna po kg, prednji dio krave 8,80-9,20 kruna po kg. Prema svjedodžbi o mjesnim cijenama živežne robe u prodaji na malo, koje su postojale 20. travnja 1917. u Zagrebačkoj županiji, stanje je bilo sljedeće: goveđe meso za pečenje 9,60-16 kruna po kg, stražnje goveđe meso za kuhanje 9,60-12 kruna po kg, prednje goveđe meso za kuhanje 8,80-9,60 kruna po kg, pšenično brašno za kuhanje (srednja vrsta) 0,76 kruna po kg, grah 1,80 kruna po kg, kiselo zelje (kupus) 0,72 kruna po $\mathrm{kg}$, sol za kuhanje 0,32 kruna po $\mathrm{kg}$, kamena sol 0,32 kruna po $\mathrm{kg}$, svinjska mast $12 \mathrm{kruna}$ po $\mathrm{kg}$, mast za pečenje $10 \mathrm{kruna}$ po $\mathrm{kg}$, pretopljeno maslo $16 \mathrm{kruna}$ po $\mathrm{kg}$, crveni luk 1,60 kruna po kg, bijeli luk 6 kruna po $\mathrm{kg}$, zelenje za juhu $2 \mathrm{krune}$ po $\mathrm{kg}$, papar 50 kruna po kg, paprika 40 kruna po kg, ocat 1,20 kruna po litri. Vidi: HR-HDA-82. Zemaljska vlada. Odjel za narodno gospodarstvo - Zagreb (1896-1923), Poslovi aprovizacije (X), ur.br. 20.209/1917, kut. br. 92. Spomenimo također, da je koncem listopada 1918. tržišna cijena meda po kilogramu iznosila oko 22 krune (u saću), a 32 krune za vrcani med. Vidi: Izvještaj o poslovanju Trgovačke i obrtničke komore u Zagrebu u ratnoj godini 1918. do proglašenja nezavisnosti Države SHS, 1918, 146.

${ }^{20}$ HR-HDA-215. MDR NDH, dosje Senjske štedionice Senj, Pravila Senjske štedionice u Senju od 3. ožujka 1901., Izvadak iz trgovačkog registra Okružnog suda u Sušaku za Senjsku štedionicu u Senju od 19. studenoga 1938., kut. br. 305.

${ }^{21}$ HR-HDA-215. MDR NDH, dosje Senjske štedionice Senj, Prijepis obrtne iskaznice Senjske štedionice od 27. ožujka 1901., kut. br. 305. 


\section{Upravna tijela Senjske štedionice Senj}

Kao što je već rečeno, temeljem Pravila Senjske štedionice društvene poslove obavljali su glavna skupština dioničara, ravnateljstvo i nadzorni odbor.

Sva prava koja su pripadala dioničarima u poslovima štedionice izvršavali su dioničari na valjano sazvanoj glavnoj skupštini (redovitoj i izvanrednoj). Dioničare je na glavnu skupštinu sazivao predsjednik ravnateljstva nakon zaključka ravnateljstva. Svaki dioničar koji je imao pravo glasa mogao je to pravo vršiti osobno ili po opunomoćeniku. Pravo glasa na glavnoj skupštini pripadalo je pojedinome dioničaru samo na temelju onih dionica, koje su barem tri mjeseca prije skupštine upisane u društvenu knjigu dionica na njegovo ime. Svakih pet dionica davalo je pravo na jedan glas, a više od deset glasova nije mogao imati niti jedan dioničar, niti u svoje ime, ni kao opunomoćenik. Korporacije, zavode, trgovačke tvrtke, žene i maloljetnike, mogli su na glavnoj skupštini zastupati samo oni dioničari kojima je u istoj skupštini pripadalo pravo glasa. Glavnom skupštinom predsjedao je predsjednik društva, a ako je bio spriječen, zamjenjivao ga je potpredsjednik. Ako ni on nije mogao predsjedavati skupštinom, tada ga je mijenjao neki drugi član ravnateljstva. Perovođu glavne skupštine određivao je predsjednik glavne skupštine. Glavna skupština raspravljala je i donosila zaključke o sljedećim predmetima: 1. izvješće ravnateljstva o poslovima društva u protekloj poslovnoj godini, 2. računi što ih je polagalo ravnateljstvo za minulu poslovnu godinu, bilanca istoga razdoblja te odredba o dividendi i dotaciji pričuvne zaklade, 3. izvješće nadzornog odbora o kontroli godišnjih računa $\mathrm{i}$ bilance te o prijedlogu ravnateljstva o razdiobi dividende, 4. izbor, odrješenje ili smjena ravnateljstva i nadzornog odbora, 5. povišenje ili umanjenje temeljne glavnice, 6. sjedinjenje društva $\mathrm{s}$ nekim drugim društvom ili poduzećem, 7. promjena društvenih pravila, 8. razlaz društva i izbor likvidatora, 9. svaki prijedlog što su ga ravnateljstvo, nadzorni odbor ili dioničari podnijeli glavnoj skupštini na raspravu ili zaključak. Ravnateljstvo je trebalo dostaviti zapisnik glavne skupštine u izvorniku ili u ovjerenom prijepisu Kr. kotarskom kao trgovačko-mjenbenom sudu u Senju.

Poslove štedionice vodilo je ravnateljstvo (pet do sedam članova), koje je izabrala glavna skupština na tri godine. Ravnateljstvo je na svojemu prvom zasjedanju izabiralo na tri godine između sebe predsjednika i potpredsjednika. Ravnateljstvo je između sebe biralo upravljajućeg ravnatelja, koji je obavljao poslove štedionice te je izvršavao zaključke ravnateljstva. Nadležnost ravnateljstva bila je sljedeća: 1. sazivanje glavne skupštine te ustanovljavanje predmeta koji su trebali biti stavljeni na dnevni red, 2. svake 
godine pregledavati izvješće o poslovanju društva te godišnju bilancu, koju je ravnatelj društva sastavljao i predlagao ravnateljstvu, 3. biranje predsjednika i potpredsjednika štedionice, 4 . biranje članova u povjerenstvo za prosuđivanje mjenica i vrijednosnih papira (Cenzuralni odbor) ${ }^{22}, 5$. ustanovljenje statuta za organizaciju službe zavodskih činovnika i za njihove plaće i beriva, 6 . dozvoljavanje hipotekarnih zajmova, 7. dozvoljavanje prijenosa društvenih dionica i 8. zastupanje društva prema trećim osobama, odnosno potpisivanje tvrtke prema odredbama ovih Pravila. Svi zaključci ravnateljstva stvarani su apsolutnom većinom glasova. Kod jednakoga broja glasova o zaključku je odlučivao predsjednik.

Nadzorni odbor sastojao se od tri redovita člana i dva zamjenika, koje je između dioničara na tri godine birala glavna skupština. Nadzorni odbor birao je iz svoje sredine pročelnika, koji je njegove članove sazivao na poslovne sjednice. Nadzorni odbor je vodio kontrolu nad poslovima društva u svim granama te je u tu svrhu bio u svako doba ovlašten informirati se o društvenim poslovima te pregledavati knjige, spise i blagajnu društva. Odbor je bio dužan ispitivati godišnje račune i bilancu te prijedloge predložene po ravnateljstvu o razdiobi dobitka. O tome je nadzorni odbor izvješćivao svake godine glavnu skupštinu. ${ }^{23}$

U ovom potpoglavlju navedeni su, kao primjer, neki članovi uprave Senjske štedionice za 1873., 1875., 1876., 1881., 1912. i 1915. Također, navedeni su upisi novih kao i brisanja istupajućih članova uprave u trgovačkom registru od 1877. do 1917.

$\mathrm{Na}$ svečanoj konstituirajućoj glavnoj skupštini Senjske štedionice održanoj 22. veljače 1873. izabran je ravnajući odbor u sastavu: Izidor Vuić kao predsjednik, podnačelnik Jerman Barac kao potpredsjednik te članovi: odvjetnik Vaso Pauković, J. N. Stanišić, Franjo Olivieri, Accurti24 ${ }^{24}$ barun Pavao Jurković, pl. Domazetović, Jovo Petrović i Stavro Lattas ${ }^{25}$. Grof Arthur Nugent ${ }^{26}$ kao najveći dioničar izabran je za počasnoga predsjednika, isto kao i biskup Vjenceslav Soić ${ }^{27}$, a N. Uric, kao koncesionar s velikim zaslugama za osnivanje štedionice,

${ }^{22}$ Mjenice i druge vrijednosne papire podnesene na eskomptiranje ispitivalo je posebno povjerenstvo (prosudnici, cenzori), koje se sastojalo od najmanje tri člana ravnateljstva. Pravovaljani zaključak donosilo je ovo povjerenstvo većinom glasova.

${ }^{23}$ HR-HDA-215. MDR NDH, dosje Senjske štedionice Senj, Pravila Senjske štedionice u Senju od 3. ožujka 1901., kut. br. 305.

${ }^{24}$ U Narodnim novinama spominje se kao Akurti.

${ }^{25}$ U Narodnim novinama spominje se kao St. Lattas.

${ }^{26}$ O ostavštini Arthura Nugenta na Trsatu vidi: Đ. VANĐURA, 1991, 131-136.

${ }^{27}$ O biskupu Vjenceslavu Soiću opširnije vidi: K. ŠKULJEVIĆ, 2012, 95-112. 
imenovan je odbornikom. Istoga dana konstituiran je ravnajući veliki odbor te je između svojih članova izabrao mali odbor ili štedioničko ravnateljstvo u sastavu: Izidor Vuić, Jerman Barac, Vaso Pauković, J. N. Stanišić i Franjo Olivieri. ${ }^{28}$

Krajem 1875. predsjednik Senjske štedionice bio je Izidor Vuić, potpredsjednik Ivan Bontić, ravnatelj i knjigovođa Rafael Lemaić, a blagajnik Stavro Lattas ${ }^{29}$. Bilo je 8 članova upravnog odbora. ${ }^{30}$

Kraljevski kotarski kao trgovački sud u Senju upisao je 24. travnja 1876. Senjsku štedionicu u novi registar za društvene tvrtke te su ujedno kao članovi ravnateljstva upisani: Izidor Vuić kao predsjednik, Ivan Bontić kao potpredsjednik te članovi Nikola Dujmović, barun Pavao Jurković, Ivan Mladineo, Emanuel Mileusnić, Franjo Olivieri i Vaso Pauković. ${ }^{31}$

Krajem 1881. ravnatelj i knjigovođa Senjske štedionice bio je Rafael Lemaić, a blagajnik J. Ciča. ${ }^{32}$

Krajem 1912. predsjednik Senjske štedionice bio je Konrad Zimpermann, potpredsjednik Mate Rukavina, a prokurista i knjigovođa Josip Geržanić. Članovi ravnateljstva bili su: Juraj Krmpotić, Franjo Rubčić, Drago Vlahović i Martin Kosina. Nadzorni odbor činili su Frane Vukelić, Dragutin Didolić i Juraj Mladineo. Blagajnik je bio Milan Milek. ${ }^{33}$

Krajem 1915. članovi ravnateljstva Senjske štedionice bili su: Drago Vlahović, Mate Rukavina, Martin Kosina, Konrad Zimpermann, Franjo Rubčić,

${ }^{28}$ Dopis od 28. veljače 1873, Narodne novine, br. 52, 4. ožujka 1873, 2-3. Kod Kraljevskog gradskog kao trgovačkog suda u Senju unesena je 8. lipnja 1873. u registar za društvene tvrtke Senjska štedionica te njezin ravnajući odbor koji su činili: Izidor Vuić kao predsjednik, Jerman Barac kao potpredsjednik te članovi Vaso Pauković, Franjo Olivieri, J. N. Stanišić, svi iz Senja. Vidi: Oglas Gradskog suda u Senju br. 964, Narodne novine, br. 137, 17. lipnja 1873, 4. Neki autori kao prvog predsjednika Senjske štedionice spominju tadašnjeg senjskog načelnika Goraninovića, a kao potpredsjednika Ivana Krajacza. Članovi upravnog odbora bili su ujedno i zastupnici grada Senja. Vidi: I. BRLIĆ, 2017, 326. U izvorima korištenima u ovome članku neki članovi uprave navedeni su samo prezimenom.

${ }^{29}$ U službenom shematizmu spominje se kao Stavro Lates.

${ }^{30}$ Compass, Finanzielles Jahrbuch für Oesterreich-Ungarn 1877, X, 1877, 484.

${ }^{31}$ Upisi tvrdkah, Narodne novine, br. 102, 4. svibnja 1876, 4. Također, vidi: HR-HDA-215. Ministarstvo državne riznice Nezavisne Države Hrvatske-Zagreb (MDR NDH), dosje Senjske štedionice Senj, Izvadak iz trgovačkog registra Okružnog suda u Sušaku za Senjsku štedionicu u Senju od 19. studenoga 1938., kut. br. 305.

${ }^{32}$ Compass, Finanzielles Jahrbuch für Oesterreich-Ungarn 1883, XVI, 1883, 354.

${ }^{33}$ Hrvatski kompas, financijalni ljetopis za 1913./14. o poslovanju privrednih institucija: banaka, štedionica, zadruga, industrialnih, parobrodarskih i inih trgovačkih poduzeća u Hrvatskoj, Slavoniji, Dalmaciji, Istri, Kranjskoj, Koruškoj, Štajerskoj, Bosni i Hercegovini, uz dodatak nekih novčanih zavoda u Ugarskoj, Srbiji i Crnoj Gori, 1913, 276. 
Josip Geržanić i Juraj Krmpotić. Nadzorni odbor činili su F. Vukelić, Grga Ratković i Julio Pavan. Ravnatelj i knjigovođa bio je Josip Geržanić. Blagajnik je bio Milan Milek. ${ }^{34}$

U nastavku slijede upisi i brisanja članova uprave Senjske štedionice u trgovačkom registru (1877. - 1917.). Dana 3. kolovoza 1877. u trgovački registar za Senjsku štedionicu upisan je kao novi član ravnateljstva Leopold Turić; 1. travnja 1879. brišu se članovi ravnateljstva Vaso Pauković, Ivan Mladineo i Lavoslav Turić, a upisuju se Jovo Petrović, Mate Babić i Ivan Stanišić; 16. travnja 1880. brišu se članovi ravnateljstva Ivan Stanišić, Jovo Petrović i barun Pavao Jurković, a istodobno se upisuju Jerko Perpić, Dragutin Accurti i J. Marusich; 20. studenoga 1880. briše se Jerko Perpić kao član ravnateljstva, a umjesto njega upisan je Svetozar Vuić; 7. travnja 1883. brišu se članovi ravnateljstva: predsjednik Izidor Vuić, Dragutin Accurti, Mato Babić, Nikola Dujmović, Ivan Bontić, Emanuel Mileusnić, Franjo Olivieri i Svetozar Vuić; 7. travnja i 7. srpnja 1883. upisuju se kao članovi ravnateljstva predsjednik Konrad Zimpermann, potpredsjednik Ladislav Krajač, Filip Ferlan, Juraj Franceschini, Antun Blažević, Martin Kosina, Nikola Miletić, Ante Devčić i Ante Divolić; 8. svibnja 1886. upisuju se kao članovi ravnateljstva Franjo Krajač i Ivan Mladineo, a brišu se Antun Blažević i Ante Didolić; 28. listopada 1886. upisan je kao tehnički ravnatelj knjigovođa Josip Geržanić35; 18. ožujka 1891. upisuje se Šime Štiglić kao član nadzornog odbora; 25. lipnja 1892. upisuje se dragovoljni istup Martina Kosine i Filipa Ferlana iz ravnateljstva; 2. ožujka 1894. briše se iz ravnateljstva Jure Franceschini jer je preminuo, a umjesto njega upisuje se Martin Kosina, kao član nadzornog odbora upisan je Drago Vlahović; 24. veljače 1897. kao član ravnateljstva briše se Anton Devčić, a umjesto njega upisuje se Josip Geržanić; 15. lipnja 1901. kao član ravnateljstva briše se Nikola Miletić, a umjesto njega upisuje se Mate Rukavina; 10. travnja 1902. kao član ravnateljstva briše se Franjo (Frane) Krajač, a umjesto njega upisuje se Šime Štiglić; 24. veljače 1908. kao član ravnateljstva briše se Josip Geržanić, a umjesto njega upisuje se Drago Vlahović; 8. travnja 1913. brišu se kao članovi ravnateljstva Šime Štiglić i Ivan Mladineo, a umjesto njih upisani su Franjo Rubčić i Josip Geržanić; 22. travnja 1917. kao član ravnateljstva briše se Martin Kosina, a umjesto njega upisuje se Grga Ratković (trgovac u Senju). ${ }^{36}$

${ }^{34}$ Ungarischer Compass 1916. - 1917, Financielles und Commercielles Jahrbuch, I. Teil: Geld und Creditinstitute, XLIV, Band I, 1916, 1628.

${ }^{35} \mathrm{U}$ dokumentu piše Gržanić, a ne Geržanić. Međutim, u većini izvornih dokumenata navodi se kao Geržanić.

${ }^{36}$ HR-HDA-215. MDR NDH, dosje Senjske štedionice Senj, Izvadak iz trgovačkog registra Okružnog suda u Sušaku za Senjsku štedionicu u Senju od 19. studenoga 1938., kut. br. 305. 


\section{Poslovanje Senjske štedionice Senj}

Početak Senjske štedionice događa se kada je Senj izgubio gotovo cijelu svoju trgovačku važnost. Neznatna početna sredstva zavoda plasiralo je tadašnje konzervativno rukovodstvo zavoda u sitne i dobro osigurane poslove (štedni ulozi, mjenice, tekući računi, hipotekarni zajmovi, vrijednosni papiri i sl.) te je na taj način osiguralo zavodu stalnu dobit, koja se redovito u nekom dijelu dodavala pričuvi. ${ }^{37}$

Kao primjer poslovanja Senjske štedionice u periodu Austro-Ugarske Monarhije u nastavku je, zbog usporedbe, navedena njezina razmjera na dane 31. prosinca 1875., 31. prosinca 1881., 31. prosinca 1899., 31. prosinca 1912., 31. prosinca 1915 i 31 . prosinca 1916.

31. prosinca 1875. račun bilance Senjske štedionice bio je sljedeći (u forintama): ${ }^{38}$

Tabl.1. Račun bilance Senjske štedionice 31. prosinca 1875.

\begin{tabular}{|l|r|l|r|}
\hline \multicolumn{2}{|c|}{ Aktiva } & \multicolumn{2}{c|}{ Pasiva } \\
\hline Posjed mjenica & 80.896 & Dionička glavnica & 34.540 \\
\hline Predujmovi na zaloge & 15.312 & Pričuvna zaklada & 786 \\
\hline Uložni kapital & 5.522 & Štedni ulozi & 79.151 \\
\hline Gotovina & 2.445 & Kamate na uloge & 3.505 \\
\hline Tekući račun & 9.338 & Razna pasiva & 179 \\
\hline Vrijednosni papiri & 4.095 & Čisti dobitak & 2.508 \\
\hline Inventar (našastar) & 2.900 & & \\
\hline Ostala imovina & 161 & & 120.669 \\
\hline Ukupno: & 120.669 & Ukupno: & \\
\hline
\end{tabular}

${ }^{37}$ HR-HDA-215. MDR NDH, dosje Senjske štedionice Senj, Izvještaj o pregledu Senjske štedionice od 26. srpnja 1927., kut. br. 305.

${ }^{38}$ Compass, Finanzielles Jahrbuch für Oesterreich-Ungarn 1877, X, 1877, 484. Godišnji podaci o poslovanju (bilance, dionički kapital, tijela upravljanja i sl.) svih novčarskih zavoda u periodu Austro-Ugarske Monarhije, Kraljevine SHS/Jugoslavije, Nezavisne Države Hrvatske objavljivani su u Compassima. Same godišnje bilance novčarskih zavoda objavljivane su i u zagrebačkim Narodnim novinama. Upućujem zainteresirane na te izvore.

${ }^{39}$ Kao što je već rečeno, dionička glavnica ustanovljena je na 50.000 forinti podijeljena na 1.000 dionica po 50 forinti. Od toga je do tada uplaćeno 35.000 forinti, ali uz 46 izdanih međutomnica (privremenica) u vrijednosti od 460 forinti. Međutomnica je isprava koja je svjedočila člansko pravo u dioničkom društvo tako dugo dok se ne bi izdala isprava o dionici. Izdavala se onda kada ulog nije bio u cijelosti uplaćen, a dioničko društvo nije htjelo dioničaru dati definitivnu ispravu. Tako je uistinu do tada uplaćena dionička glavnica iznosila 34.540 forinti (35.000 forinti - 460 još neuplaćenih forinti). 
31. prosinca 1881. račun bilance Senjske štedionice bio je sljedeći (u forintama): ${ }^{40}$

Tabl. 2. Račun bilance Senjske štedionice 31. prosinca 1881.

\begin{tabular}{|l|r|l|r|}
\hline \multicolumn{2}{|c|}{ Aktiva } & \multicolumn{2}{c|}{ Pasiva } \\
\hline Posjed mjenica & 68.298 & Dionička glavnica ${ }^{41}$ & 35.000 \\
\hline Hipotekarni zajmovi & 31.931 & Pričuvna zaklada & 4.788 \\
\hline Predujmovi & 16.495 & Štedni ulozi & 109.597 \\
\hline Vrijednosni papiri & 3.185 & Razna pasiva & 538 \\
\hline Dužnici u tekućem računu & 24.680 & Čisti dobitak & 2.178 \\
\hline Blagajna & 5.107 & & \\
\hline Ostala imovina & 2.405 & & 152.101 \\
\hline Ukupno: & 152.101 & Ukupno: & \\
\hline
\end{tabular}

31. prosinca 1899. razmjera Senjske štedionice bila je sljedeća (u krunama): ${ }^{42}$

Tabl. 3. Račun bilance Senjske štedionice 31. prosinca 1899.

\begin{tabular}{|l|r|l|r|}
\hline \multicolumn{2}{|c|}{ Aktiva (imovina) } & \multicolumn{2}{c|}{ Pasiva (dugovina) } \\
\hline Gotovina & 7.898 & Dionička glavnica & 70.000 \\
\hline Posjed mjenica & 261.564 & Pričuvna zaklada & 32.596 \\
\hline Hipotekarni zajmovi & 17.140 & Štedni ulozi & 287.464 \\
\hline Založnice & 6.110 & Reeskonti & 7.130 \\
\hline Predujmovi na zaloge & 9.578 & Porez na kamate & 552 \\
\hline Dužnici & 38.564 & Nepodignuti dividendi & 900 \\
\hline Nepokretnine & 66.000 & Čisti dobitak & 9.012 \\
\hline Poslovni namještaj & 800 & & 407.654 \\
\hline Ukupno: & 407.654 & Ukupno: & \\
\hline
\end{tabular}

${ }^{40}$ Compass, Finanzielles Jahrbuch für Oesterreich-Ungarn 1883, XVI, 1883, 354.

${ }^{41}$ Dionička glavnica iznosila je 35.000 forinti podijeljena na 1.000 dionica po 35 forinti.

${ }^{42}$ Mihók'scher Ungarischer Compass, 1900./1901, Financielles und Commercielles Jahrbuch, I. Theil: Banken und Sparcassen in Oesterreich-Ungarn, XXVIII, 1900, 846.

${ }^{43}$ Dionička glavnica iznosila je 70.000 kruna sastojeća iz 1.000 komada dionica glaseće na ime po 70 kruna. Zakonskim člankom XXXVI. o uvođenju obće obvezatnoga računanja u krunskoj vrednoti od 21. rujna 1899, krunska vrednota koja je ustanovljena već navedenim Zakonskim člankom XVII. iz 1892. stupila je počevši od 1. siječnja 1900. kao jedina i isključivo zakonska vrednota na mjesto austrijske vrednote. Jedan forint austrijske vrednote računao se kao dvije krune, a jedan novčić austrijske vrednote kao dva filira. Vidi: Sbornik zakonah i naredabah valjanih za Kraljevine Hrvatsku i Slavoniju, godina 1899, br. 94, 1899, 893-898. Tako je dotadašnja uplaćena dionička glavnica banke od 35.000 forinti preinačena na 70.000 kruna. 
31. prosinca 1912. razmjera Senjske štedionice bila je sljedeća (u krunama): ${ }^{44}$

Tabl. 4. Račun bilance Senjske štedionice 31. prosinca 1912.

\begin{tabular}{|l|r|l|r|}
\hline \multicolumn{2}{|c|}{ Aktiva } & \multicolumn{2}{c|}{ Pasiva } \\
\hline Gotovina na blagajni & $16.406,48$ & Dionička glavnica & 70.000 \\
\hline Mjenice & $618.136,80$ & Pričuvna zaklada & 108.000 \\
\hline $\begin{array}{l}\text { Predujmovi na vrijednosne } \\
\text { stvari }\end{array}$ & $4.455,20$ & Ulozi & $663.959,93$ \\
\hline Zajmovi na nekretnine & 75.700 & Reeskont & 91.500 \\
\hline Dužnici u tekućem računu & $215.796,21$ & Nedignuta dividenda & 992,12 \\
\hline Vlastite nekretnine & 35.100 & Posebna pričuva & $10.951,85$ \\
\hline Inventar & 350 & Dobrotvorna zaklada & $1.602,59$ \\
\hline & & Porez na kamate uloga & $1.342,80$ \\
\hline & & Čisti dobitak & $17.595,40$ \\
\hline Ukupno: & $965.944,69$ & Ukupno: & $965.944,69$ \\
\hline
\end{tabular}

$\mathrm{Na}$ isti dan račun gubitka i dobitka bio je sljedeći (u krunama): ${ }^{45}$

Tabl. 5. Račun gubitka i dobitka Senjske štedionice 31. prosinca 1912.

\begin{tabular}{|l|r|l|r|}
\hline \multicolumn{2}{|c|}{ Gubitak } & \multicolumn{2}{c|}{ Dobitak } \\
\hline Kamati uloga & $25.869,67$ & Najamnina vlastitih kuća & 2.690 \\
\hline 10\% porez na kamate uloga & $2.586,97$ & Razni kamati & $61.212,19$ \\
\hline Reeskontni i povraćeni kamati & $5.417,50$ & Providbe & $2.147,80$ \\
\hline Upravni troškovi & $1.553,18$ & & \\
\hline Porez, pristojbe i drugo & $2.290,27$ & & \\
\hline Najamnina & 600 & & \\
\hline Beriva & 10.087 & & \\
\hline Otpis od inventara & 50 & & $66.049,99$ \\
\hline Čisti dobitak & $17.595,40$ & & \\
\hline Ukupno: & $66.049,99$ & Ukupno: & \\
\hline
\end{tabular}

${ }^{44}$ Hrvatski kompas, financijalni ljetopis za 1913./14. o poslovanju privrednih institucija: banaka, štedionica, zadruga, industrialnih, parobrodarskih i inih trgovačkih poduzeća u Hrvatskoj, Slavoniji, Dalmaciji, Istri, Kranjskoj, Koruškoj, Štajerskoj, Bosni i Hercegovini, uz dodatak nekih novčanih zavoda u Ugarskoj, Srbiji i Crnoj Gori, 1913, 276.

${ }^{45}$ Hrvatski kompas, financijalni ljetopis za 1913./14. o poslovanju privrednih institucija: banaka, štedionica, zadruga, industrialnih, parobrodarskih i inih trgovačkih poduzeća u Hrvatskoj, Slavoniji, Dalmaciji, Istri, Kranjskoj, Koruškoj, Štajerskoj, Bosni i Hercegovini, uz dodatak nekih novčanih zavoda u Ugarskoj, Srbiji i Crnoj Gori, 1913, 276. 
Broj štednih uloga krajem 1912. bio je 500, kamate 4,5\%, mjenbeni portefeuille 519 komada, kamate $7-8 \%$, broj hipotekarnih zajmova 14 , a kamate $7 \frac{1}{2} \%$. Ukupni promet 1912. godine iznosio je 6,978.806,54 kruna.

Za usporedbu spomenimo poslovanje nekoliko drugih štedionica u 1912. godini. Tako je, primjerice, Novogradiška štedionica d.d. Nova Gradiška imala dioničku glavnicu od 600.000 kruna, a čisti dobitak od 145.247,63 kruna. Pučka dionička štediona Nova Gradiška imala je dioničku glavnicu od 200.000 kruna, a čisti dobitak od 52.814,28 kruna. Zelinska dionička štediona Sv. Ivan Zelina imala je dioničku glavnicu od 120.000 kruna, a čisti gubitak od 28.957,06 kruna. Samoborska štedionica Samobor imala je dioničku glavnicu od 100.000 kruna, a čisti dobitak od 42.533,95 kruna. Hrvatska katolička štediona d.d. Nova Gradiška imala je dioničku glavnicu od 100.000 kruna, a čisti dobitak od 16.019,18 kruna. Pučka štedionica d.d. Jastrebarsko imala je dioničku glavnicu od 100.000 kruna, a čisti dobitak od 12.424,62 kruna. Jastrebarska dionička štedionica Jastrebarsko imala je dioničku glavnicu od 120.000 kruna, a čisti dobitak od 39.739,87 kruna. Našička štedionica Našice imala je dioničku glavnicu od 120.000 kruna, a čisti dobitak od 38.843,75 kruna. Od velebanaka, Prva hrvatska štedionica Zagreb, kao naš najstariji i najznačajniji novčarski zavod, imala je dioničku glavnicu od 6,000.000 kruna, a čisti dobitak 1,327.428,91 kruna (s prijenosom dobitka iz 1911. godine od 158.262,05 kruna, iznosio je ukupni dobitak 1,485.690,96 kruna). Od većih banaka spomenimo i Srpsku banku d.d. Zagreb koja je imala dioničku glavnicu od 6,000.000 kruna te čisti dobitak od 468.694,20 kruna. ${ }^{46}$

31. prosinca 1915. razmjera Senjske štedionice bila je sljedeća (u krunama): ${ }^{47}$

Tabl. 6. Razmjera Senjske štedionice 31. prosinca 1915.

\begin{tabular}{|l|r|l|r|}
\hline \multicolumn{2}{|c|}{ Aktiva (imovina) } & \multicolumn{2}{c|}{ Pasiva (dugovina) } \\
\hline Blagajna & 17.185 & Dionička glavnica & 70.000 \\
\hline Mjenična lisnica & 556.304 & Pričuvna zaklada & 124.000 \\
\hline Hipotekarni zajmovi & 77.400 & Posebna pričuva & 19.452 \\
\hline Predujmovi na zaloge & 3.753 & Dobrotvorna zaklada & 4.254 \\
\hline Dužnici & 238.529 & Štedni ulozi & 683.222 \\
\hline
\end{tabular}

${ }^{46}$ Hrvatski kompas, financijalni ljetopis za 1913./14. o poslovanju privrednih institucija: banaka, štedionica, zadruga, industrialnih, parobrodarskih i inih trgovačkih poduzeća u Hrvatskoj, Slavoniji, Dalmaciji, Istri, Kranjskoj, Koruškoj, Štajerskoj, Bosni i Hercegovini, uz dodatak nekih novčanih zavoda u Ugarskoj, Srbiji i Crnoj Gori, 1913, 80-97, 133-136, 184-185, 215-220, 273, 2952-96.

${ }^{47}$ Ungarischer Compass 1916.-1917, Financielles und Commercielles Jahrbuch, I. Teil: Geld und Creditinstitute, XLIV, Band I, 1916, 1628. 


\begin{tabular}{|l|r|l|r|}
\hline Nepokretnine & 35.100 & Reeskont & 17.000 \\
\hline Inventar (našastar) & 2.650 & Dividende & 489 \\
\hline & & Porez na kamate & 1.469 \\
\hline & & Čisti dobitak & 11.035 \\
\hline Ukupno: & 930.921 & Ukupno: & 930.921 \\
\hline
\end{tabular}

31. prosinca 1916. razmjera Senjske štedionice bila je sljedeća (u krunama): ${ }^{48}$

Tabl. 7. Razmjera Senjske štedionice 31. prosinca 1916.

\begin{tabular}{|l|r|l|r|}
\hline \multicolumn{2}{|c|}{ Aktiva (imovina) } & \multicolumn{2}{c|}{ Pasiva (dugovina) } \\
\hline Novčana gotovina (blagajna) & $25.121,05$ & Dionička glavnica & $70.000 .-$ \\
\hline Mjenice & $464.499,84$ & Pričuvna zaklada & $126.000 .-$ \\
\hline $\begin{array}{l}\text { Predujmovi na vrijednosne } \\
\text { stvari }\end{array}$ & $3.336,80$ & Ulozi & $646.953,53$ \\
\hline Zajmovi na nekretnine & $64.800 .-$ & Nepodignuta dividenda & $926 .-$ \\
\hline Dužnici u tekućem računu & $272.590 .-$ & Posebna pričuva & $22.486,94$ \\
\hline Vlastite nekretnine & $35.100 .-$ & Dobrotvorna zaklada & $4.254,63$ \\
\hline Vrijednosni papiri & $13.875 .-$ & Porez na kamate uloga & $1.436,48$ \\
\hline Inventar & $2.500 .-$ & Čisti dobitak & $9.765,11$ \\
\hline Ukupno: & $881.822,69$ & Ukupno: & $881.822,69$ \\
\hline
\end{tabular}

Na isti dan račun gubitka i dobitka bio je sljedeći (u krunama): ${ }^{49}$

Tabl. 8. Račun gubitka i dobitka Senjske štedionice 31. prosinca 1916.

\begin{tabular}{|l|r|l|r|}
\hline \multicolumn{2}{|c|}{ Rashod } & \multicolumn{2}{c|}{ Prihod } \\
\hline Kamati uloga & $29.115,43$ & Najamnina vlastitih kuća & $2.836 .-$ \\
\hline 10\% porez na kamate uloga & $2.911,54$ & Razni kamati & $49.494,44$ \\
\hline Reeskontni i povraćeni kamati & 93,68 & Providbe & $3.683,16$ \\
\hline Upravni troškovi & $1.262,59$ & & \\
\hline Porez, pristojbe i drugo & $2.174,25$ & & \\
\hline Najamnina & $600 .-$ & & \\
\hline Beriva & $9.941 .-$ & & \\
\hline Otpis od inventara & $150 .-$ & & \\
\hline Čisti dobitak & $9.765,11$ & & $56.013,60$ \\
\hline Ukupno: & $56.013,60$ & Ukupno: & \\
\hline
\end{tabular}

${ }^{48}$ HR-HDA-215. MDR NDH, dosje Senjske štedionice Senj, XLIV. zaključak računa Senjske štedionice o poslovnoj godini 1916., kut. br. 305.

${ }^{49}$ HR-HDA-215. MDR NDH, dosje Senjske štedionice Senj, XLIV. zaključak računa Senjske štedionice o poslovnoj godini 1916., kut. br. 305. 
U dosad pronađenim izvorima i objavljenoj literaturi ne navodi se podatak o poslovanju štedionice za 1918. godinu. Treba napomenuti da se, temeljem Pravila Senjske štedionice, svaka glavna skupština sazivala oglasom uvrštenim barem jedanput u službenim hrvatskim novinama (Narodne novine). U oglasu se navodilo mjesto i vrijeme te dnevni red rasprave. ${ }^{50} \mathrm{Uz}$ navedene podatke, u Narodnim novinama objavljivane su i godišnje bilance te često i imena i prezimena članova ravnateljstva i nadzornog odbora. Nažalost, u oglasu o sazivanju glavne skupštine Senjske štedionice koja se trebala održati 30. ožujka 1919., osim podataka o vremenu i mjestu održavanja te dnevnog reda, ne navodi se godišnja bilanca za 1918., kao ni članovi uprave. Navodi se samo predsjednik štedionice C. Zimpermann ${ }^{51}$ kao potpisnik oglasa. ${ }^{52}$ Treba napomenuti da je većina novčarskih zavoda objavila u Narodnim novinama svoju bilancu za 1918. Analizom objavljenih podataka o poslovanju štedionice u Austro-Ugarskoj Monarhiji te usporedbom s drugim lokalnim novčarskim zavodima, s obzirom na njezinu dioničku glavnicu od svega 70.000 kuna i konstantno poslovanje s dobitkom, možemo zaključiti da je Senjska štedionica predstavljala manji, ali uspješan lokalni novčarski zavod.

\section{Djelovanje Senjske štedionice Senj u Kraljevini Srba, Hrvata i Slovenacal Jugoslaviji}

\section{Obrtna dozvola Senjske štedionice Senj}

Temeljem čl. 456. Zakona o radnjama ${ }^{53}$ Gradsko načelstvo u Senju izdalo je 27. svibnja 1932. pod br. 2.405/1932. uvjerenje Senjskoj štedionici kojim je potvrđeno da je prijavila ovoj oblasti svoj obrt glaseći na "novčani zavod". Ovo uvjerenje uneseno je u novi obrtni registar I. pod br. 7.54

${ }^{50}$ HR-HDA-215. MDR NDH, dosje Senjske štedionice Senj, Pravila Senjske štedionice u Senju od 3. ožujka 1901., kut. br. 305.

${ }^{51}$ Riječ je o Konradu Zimpermannu.

${ }^{52}$ Poziv na XLVI. redovitu glavnu skupštinu dioničara Senjske štedionice od 15. veljače 1919., Narodne novine, br. 49, 28. veljače 1919., str. 6.

${ }^{53}$ Obrtni zakon iz godine 1884. prestao je važiti 5. studenoga 1931. donošenjem Zakona o radnjama. Temeljem čl. 456. Zakona o radnjama, svaka osoba koja je obavljala jednu radnju ili zanimanje koje je potpadalo pod ovaj Zakon, bila je dužna u roku od 3 mjeseca poslije stupanja na snagu ovoga Zakona prijaviti svoju radnju odnosno zanimanje nadležnoj općoj upravnoj vlasti prvog stupnja. Vidi: Službene novine Kraljevine Jugoslavije, br. 262, 9. studenoga 1931., 1643.

${ }^{54}$ HR-HDA-215. MDR NDH, dosje Senjske štedionice Senj, Prijepis uvjerenja obrtne iskaznice Senjske štedionice od 27. svibnja 1932., kut. br. 305. 
Temeljem već navedenoga čl. 456. Zakona o radnjama od 5. studenoga 1931., Trgovinsko odjeljenje Ministarstva trgovine i industrije u Beogradu izdalo je 3. prosinca 1938. pod br. 45.812 dozvolu Senjskoj štedionici da može: 1. primati novac na uložne knjižice i na tekući račun, 2. eskontirati i reeskontirati mjenice i druge vrijednosne papire, 3. davati zajmove na ručni zalog i na podlozi hipoteka, 4. kupovati i prodavati vrijednosne papire, devize i valute i 5. obavljati sve vrste bankarskih poslova. Stručni poslovođa štedionice bio je Filip Kriškovićs ${ }^{5}$. Ova dozvola upisana je kod Kr. banske uprave u registru radnji pod br. 1.447/1938..$^{56}$ Temeljem navedene dozvole, Gradsko poglavarstvo u Senju donijelo je 29. prosinca 1938. odluku da se Senjska štedionica može baviti navedenim poslovima. ${ }^{57}$

\section{Povišenja dioničke glavnice Senjske štedionice Senj}

Temeljem zaključka glavne skupštine dioničara Senjske štedionice od 13. lipnja 1919. povišena je dionička glavnica na 150.000 kruna, time što je 80.000 kruna oduzeto od pričuvne zaklade i nadodalo se postojećoj dioničkoj glavnici. Ova je glavnica razdijeljena na 1.000 dionica, svaka po 150 kruna, te je u potpunosti uplaćena. ${ }^{58}$

Dana 1. svibnja 1922. zabilježeno je u trgovačkom registru da je temeljna dionička glavnica Senjske štedionice iznosila 1,500.000 kruna, razdijeljena na 10.000 dionica svaka po 150 kruna. Dozvoljeno je novo povišenje glavnice na 3,000.000 kuna time što je ravnateljstvo štedionice ovlašteno predložiti javnoj supskripciji 10.000 komada dionica uz nominalnu vrijednost od 150 kruna svaka. ${ }^{59}$

${ }^{55}$ Filip Krišković rođen je 12. siječnja 1896. u Novom Vinodolskom, rimokatolik, osam razreda gimnazije s maturom i bankovnom praksom, otac Mihovil, majka Marija, rođena Maričić. Vidi: HR-HDA-215. MDR NDH, dosje Senjske štedionice Senj, dopis Senjske štedionice upućen 8. studenoga 1940. Odjelu za obrt, industriju i trgovinu Banske vlasti Banovine Hrvatske u Zagrebu, ur.br. 69.120/1940., kut. br. 305

${ }^{56}$ HR-HDA-215. MDR NDH, dosje Senjske štedionice Senj, Dozvola Ministarstva trgovine i industrije br. 45.812 od 3. prosinca 1938., ur.br. 37.457/1942., kut. br. 305.

${ }^{57}$ HR-HDA-215. MDR NDH, dosje Senjske štedionice Senj, Odluka Gradskog poglavarstva u Senju od 29. prosinca 1938., ur.br. 37.457/1942., kut. br. 305.

${ }^{58}$ HR-HDA-215. MDR NDH, dosje Senjske štedionice Senj, Izvadak iz trgovačkog registra Okružnog suda u Sušaku za Senjsku štedionicu u Senju od 19. studenoga 1938., kut. br. 305 .

${ }^{59}$ HR-HDA-215. MDR NDH, dosje Senjske štedionice Senj, Izvadak iz trgovačkog registra Okružnog suda u Sušaku za Senjsku štedionicu u Senju od 19. studenoga 1938., kut. br. 305 . 
Dana 25. travnja 1923. zabilježeno je u trgovačkom registru da je temeljna dionička glavnica Senjske štedionice iznosila 3,000.000 kruna, razdijeljena na 20.000 dionica svaka po 150 kruna. Dozvoljeno je novo povišenje glavnice na 4,500.000 kruna time što je ravnateljstvo štedionice ovlašteno predložiti javnoj supskripciji 10.000 komada dionica uz nominalnu vrijednost od 150 kruna svaka. ${ }^{60}$

Odlukom Kr. kotarskog suda u Senju br. 3.000 gr.R.70/1906./ od 2 . siječnja 1924., temeljna dionička glavnica Senjske štedionice iznosila je 4,500.000 kruna, razdijeljenih na 22.500 komada dionica, svaka po 200 kruna. Dozvoljeno je novo povišenje glavnice na 8,000.000 kruna time što je ravnateljstvo štedionice ovlašteno predložiti javnoj supskripciji 17.500 komada dionica uz nominalnu vrijednost od 200 kruna svaka. ${ }^{61}$

Dana 2. travnja 1929. komesari Ministarstva trgovine i industrije izvršili su nadzor nad radom i stanjem Senjske štedionice. Prema njihovim podacima dionička glavnica za godinu 1928. iznosila je 1,125.000 dinara ${ }^{62}$. Dionički je kapital bio formalno uplaćen i sav je bio u domaćim rukama. ${ }^{63}$ Navedena dionička glavnica nije se mijenjala do raspada Kraljevine Jugoslavije, odnosno do početka 2. svjetskog rata.

${ }^{60}$ HR-HDA-215. MDR NDH, dosje Senjske štedionice Senj, Izvadak iz trgovačkog registra Okružnog suda u Sušaku za Senjsku štedionicu u Senju od 19. studenoga 1938., kut. br. 305 .

${ }^{61}$ HR-HDA-215. MDR NDH, dosje Senjske štedionice Senj, Pravila Senjske štedionice u Senju od 3. ožujka 1901., sa svim unesenim izmjenama do 1940. godine; Izvadak iz trgovačkog registra Okružnog suda u Sušaku za Senjsku štedionicu u Senju od 19. studenoga 1938., kut. br. 305.

${ }^{62}$ Temeljem Zakona o konačnom odnosu krunske novčanice prema dinarskoj od 31. prosinca 1921., za novčanice Austro-Ugarske banke koje su primljene kao nacionalni novac, s time što su žigosane pa zatim markirane i koje su potom zamijenjene za krunsko-dinarske novčanice u odnosu 4 markirane krune za 1 dinar, utvrđen je kao stalan i konačan odnos kruna prema dinarskoj novčanici: 4 krune za 1 dinar po kojem je zamjena i izvršena. Vidi: Službene novine Kraljevine Srba, Hrvata i Slovenaca, br. 238, 25. listopada 1922., 4-5. Tako je dotadašnja uplaćena dionička glavnica banke od 4,500.000 kruna preinačena na 1,125.000 dinara. To je potvrdilo i Ministarstvo financija svojom odlukom br. 30.855 od 30. lipnja 1924. te je dozvolilo Senjskoj štedionici da svoje dionice zamijeni sa 22.500 komada dionica po 50 dinara glasećih na ime, tako da je dionička glavnica iznosila 1,125.000 dinara. Vidi: HR-HDA-620. Služba likvidacije starih poslova centrale Narodne banke Jugoslavije u Zagrebu (SLSP CNBJZ), 8.109.2. Upravni poslovi u vezi likvidacije Senjske štedionice, dopis Senjske štedionice upućen početkom 1946. Financijskom odjelu Okružnog narodnog odbora za Hrvatsko Primorje, kut. br. 282 .

${ }^{63}$ HR-HDA-215. MDR NDH, dosje Senjske štedionice Senj, Izvještaj o pregledu rada i stanja Senjske štedionice u Senju od 2. travnja 1929., kut. br. 305. 


\section{Dioničari Senjske štedionice Senj}

8. studenoga 1940. dioničari Senjske štedionice bili su: 1. dr. Ante Lončarić, Senj, 2. Viktor Benzia, Senj, 3. mr. ph. Jerko Dominis, Senj, 4. prof. Božo Katalinić, Otočac, 5. Nikola Katalinić, Senj, 6. Josip Murković, Stajnica, 7. Petar Ostrman, Senj, 8. Vladimir Parac, Brinje, 9. Petar Šimatić, Senj, 10. dr. Ante Vlahović, Senj, 11. Franjo Bezjak, Senj, 12. Matija Moguš, Senj, 13. Stipe Vukelić, Senj, 14. Filip Krišković, Senj, 15. Stjepan Dragičević, Senj, 16. Senjska štedionica, Senj ${ }^{64}$, 17. Jakov Pajdaš, Senj, 18. Juraj Biondić, Senj, 19. Josip Zorko, Senj, 20. Olga Erić, Zagreb, 21. mr. ph. Oskar Vičević, Ogulin, 22. prof. Miroslav Sušić, Sušak, 23. Drago Ratković, Senj, 24. Anton Vrhovac, Senj, 25. Karlo Mladineo, Senj, 26. Milan Brajković, Senj, 27. Josip Antić, Senj, 28. Josip Smetana, Senj, 29. Vjekoslav Antić, Senj, 30. Romeo Bezjak, Senj, 31. Drago Vlahović, Senj, 32. Tomo Vukušić, Senj, 33. Franjo Šojat, Senj, 34. Jakov Čanić, Senj, 35. Ivan Mihovilić, Senj, 36. Marinka Geržanić, Senj, 37. Vinko Vlahović, Senj, 38. Milan Šojat, Senj, 39. Juraj Brlečić, Senj, 40. prof. Jakov Bosnić, Senj, 41. Josip Geržanić, Senj, 42. Ljubo Rukavina, Senj, 43. Juraj Tićak, Senj, 44. Ivan Novak, Zagreb, 45. prof. MarkoVeršić, Zagreb, 46. mr. ph. Franjo Častek, Otočac, 47. Ivan Špalj, Senj, 48. Niko Rukavina, Senj, 49. Eugen Scarpa, Senj, 50. Zvonko Prpić, Senj, 51. Stjepan Šojat, Senj, 52. Vladimir-Slave Olivieri, Senj, 53. Konrad Nabršnigg, Senj, 54. Biskupski Ordinarijat, Senj, 55. Mića Prpić, Senj, 56. Josip Krišković, Senj, 57. Matija Glažar, Senj, 58. Ivan Stanišić, Senj, 59. dr. Nikola Zdunić, Senj, 60. Krsto pl. Vuković, Jezerane, 61. Marko Katalinić, Povile, 62. Lamberto Krišković, Zagreb, 63. Blaž Vukelić, Krasno, 64. Ilija Bogdanić, Lešće, 65, Luka Kolaković, Otočac, 66. Josip Orešković, Otočac, 67. Cvjeta Juhn, 68. Franceschini, 69. Lovro Vidrić, 70. Danica Dujmović, 71. Vilko Tauzani, 72. Levin Schlenger, 73. Ladislav Krajač, 74. Klara Wolfensohn (Vilim Grüwald). ${ }^{65}$

${ }^{64}$ Dionice su mogle kupiti i fizičke i pravne osobe. Senjska štedionica kao pravna osoba kupila je 1934 komada svojih dionica u ukupnoj nominalnoj vrijednosti od 96.700 dinara te je na taj način postala dioničar.

${ }^{65}$ HR-HDA-215. MDR NDH, dosje Senjske štedionice Senj, Popis dioničara Senjske štedionice u Senju od 8. studenoga 1940., kut. br. 305. U prvotnom popisu dioničara Senjske štedionice koji je registriran 8. studenoga 1940. kod Odjela za obrt, industriju i trgovinu banske vlasti pod brojem 69.120/1940., navedeno je samo prvih 39 dioničara. U drugom popisu dioničara od 8. studenoga 1940., navodi se 74 dioničara, od kojih je 66 napisano pisaćim strojem, a ostali su nadopisani rukom te su prilično nečitki. 


\section{Upravna tijela i namještenici Senjske štedionice Senj}

U ovom potpoglavlju navedeni su, kao primjer, neki članovi uprave Senjske štedionice za 1920., 1927., 1929., 1938., 1939. i 1941. godinu te namještenici štedionice za 1938. i 1939. Također, navedeni su upisi novih kao i brisanja istupajućih članova uprave u trgovačkom registru od 1920. do 1935. godine.

Krajem 1920. predsjednik Senjske štedionice bio je Drago Vlahović, potpredsjednik Mate Rukavina, ravnatelj Josip Geržanić, a blagajnik Milan Milek. ${ }^{66}$ Krajem 1926. stanje je bilo neznatno drugačije. Predsjednik štedionice bio je Juraj Krmpotić, ravnatelj Josip Geržanić, a blagajnik je i dalje bio Milan Milek. ${ }^{67}$

U veljači 1927. preminuo je Srećko Crnić, član nadzornog odbora štedionice. Ravnateljstvo štedionice zahvalilo se 29. travnja 1927. na članstvu u ravnateljstvu Josipu Sumajstorčiću, a 14. lipnja 1927. Milanu Brajkoviću, obojici zbog preopterećenosti vlastitim poslovima. ${ }^{68}$

Krajem 1929. predsjednik Senjske štedionice bio je Juraj Krmpotić, potpredsjednik dr. Ante Lončarić, ravnatelj Ivica Dragičević, a blagajnik je i dalje bio Milan Milek. ${ }^{69}$

Godine 1938. članovi ravnateljstva štedionice bili su: dr. Ante Lončarić (predsjednik, kanonik-župnik, Senj), Viktor Benzia (potpredsjednik, veletrgovac, Senj), mr. ph. Jerko Dominis (ljekarnik, Senj), Božo Katalinić (direktor gimnazije u mirovini, Senj), Nikola Katalinić (trgovac, Senj), Josip Murković (industrijalac, Stajnica), Petar Ostrman (građevinski poduzetnik, Senj), Vladimir Parac (industrijalac, Brinje), Petar Šimatić (vlasnik internata "Palestra", Senj) i dr. Ante Vlahović (odvjetnik, Senj). Članovi nadzornog odbora bili su: Franjo Bezjak (bankovni činovnik u mirovini, Senj), Matija Moguš (gostioničar, Senj) i Stipe Vukelić (mesarski obrtnik, Senj). Njihovi zamjenici bili su: Anton Vrhovac (trgovac, Senj) i Juraj Brlečić (trgovac, Senj). ${ }^{70}$ Iste godine namještenici Senjske štedionice bili su: Filip Krišković (upravitelj), Nevenka Katalinić-Drnjević, Vladimir Benzia, Anton Butorac

${ }^{66}$ Compass, Finanzielles Jahrbuch Tschechoslovakei-Jugoslavien 1922, LV, II. Band, 1922, 1144.

${ }^{67}$ Compass, Finanzielles Jahrbuch Jugoslavien 1928, LXI, 1928, 274.

${ }^{68}$ HR-HDA-215. MDR NDH, dosje Senjske štedionice Senj, Izvještaj ravnateljstva Senjske štedionice za glavnu skupštinu od 12. lipnja 1927., kut. br. 305 .

${ }^{69}$ Compass, Finanzielles Jahrbuch Jugoslavien 1931, LXIV, 1931, 381.

${ }^{70}$ HR-HDA-152. Savska financijska direkcija-Zagreb (SFD), dosje Senjske štedionice Senj, Popis članova ravnateljstva i nadzornog odbora, kut. br. 260. 
(podvornik do konca veljače 1938.) i Petar Prpić (podvornik od 1. ožujka 1938.). ${ }^{71}$

Krajem 1939. predsjednik štedionice bio je dr. Ante Lončarić, a ravnatelj Filip Krišković. Članovi nadzornog odbora bili su Matija Moguš, Franjo Bezjak i Stipe Vukelić. ${ }^{72}$ Iste godine namještenici Senjske štedionice bili su: Filip Krišković (upravitelj), Nevenka Katalinić (činovnica), Rudolf Nöthig (činovnik), Slavo Tomljanović (vježbenik) i Petar Prpić (podvornik). ${ }^{73}$

Dana 24. ožujka 1941. članovi ravnateljstva Senjske štedionice bili su: dr. Ante Lončarić, Viktor Benzia, mr. ph. Jerko Dominis, prof. Božo Katalinić, Nikola Katalinić, Josip Murković, Petar Ostrman, Vladimir Parac, Petar Šimatić i dr. Ante Vlahović. Članovi nadzornog odbora bili su: Franjo Bezjak, Matija Moguš, Stipe Vukelić, Anton Vrhovac i Juraj Brlečić. ${ }^{74}$

U nastavku slijede upisi i brisanja članova uprave Senjske štedionice u trgovačkom registru (od 1920. do 1935.). Dana 10. ožujka 1920. u trgovačkom registru za Senjsku štedionicu brisan je kao član ravnateljstva Konrad Zimpermann, a umjesto njega upisuje se Drago Vlahović (veletržac i posjednik u Senju); 9. travnja 1920. kao član ravnateljstva upisan je Juraj Mladineo (trgovac iz Senja); 22. srpnja 1922. upisuju se kao članovi ravnateljstva Josip Prpić (veletržac iz Zagreba) i Josip Sumajstorčić (posjednik iz Otočca); 20. lipnja 1924. brišu se članovi ravnateljstva Mate Rukavina i Franjo Rubčić jer su preminuli, a upisuju se dr. Ante Lončarić (kanonik iz Senja) i Milan Brajković (trgovac iz Senja); 9. travnja 1925. briše se dotadašnji predsjednik i član ravnateljstva Drago Vlahović jer je preminuo, a upisuje se Juraj Krmpotić kao novi predsjednik štedionice; 11. lipnja 1926. briše se član ravnateljstva Josip Prpić iz Zagreba; 20. srpnja 1927. brišu se članovi ravnateljstva Milan Brajković iz Senja i Josip Sumajstorčić iz Otočca, a upisuju se Viktor Benzia (trgovac iz Senja), Ivica Dragičević (trgovac iz Senja) i Miroslav Sušić (profesor iz Senja); 1. kolovoza 1928. briše se član ravnateljstva Grga Ratković (trgovac

${ }^{71}$ HR-HDA-152. SFD, dosje Senjske štedionice Senj, Iskaz namještenika u god. 1938., kut. br. 260 .

${ }^{72}$ HR-HDA-152. SFD, dosje Senjske štedionice Senj, Izvještaj ravnateljstva Senjske štedionice o poslovanju za 1939. godinu, 27. travnja 1940.; Poziv ravnateljstva Senjske štedionice od 14. travnja 1940. na LXVII. redovitu glavnu skupštinu koja se održala 5. svibnja 1940., kut. br. 260.

${ }^{73}$ HR-HDA-152. SFD, dosje Senjske štedionice Senj, Iskaz namještenika u god. 1939., kut. br. 260 .

${ }^{74}$ HR-HDA-215. MDR NDH, dosje Senjske štedionice Senj, Popis sadanjih članova ravnateljstva i nadzornog odbora Senjske štedionice, 24. ožujka 1941., ur.br. 18.131/1941., kut. br. 305 . 
iz Senja), a upisuje se Zvonko Prpić (pekarski obrtnik iz Senja); 13. lipnja 1929. briše se član ravnateljstva Josip Geržanić iz Senja, a upisuju se novi članovi ravnateljstva Filip Krišković, Nikola Katalinić i Ivan Špalj iz Senja; 16. travnja 1931. briše se član ravnateljstva Zvonko Prpić; 19. veljače 1932. briše se Juraj Krmpotić, kao predsjednik, a upisuju se dr. Antun Lončarić (župnik i kanonik), kao predsjednik i Nikola Katalinić, kao potpredsjednik; 9. ožujka 1932. briše se kao član ravnateljstva Juraj Krmpotić (trgovac iz Senja); 22. lipnja 1932. briše se Nikola Katalinić, kao član ravnateljstva i potpredsjednik, a upisuju se Viktor Benzia kao potpredsjednik, Petar Šimatić kao član ravnateljstva i Ivica Dragičević kao upravljajući ravnatelj; 16. studenoga 1935. brisani su članovi ravnateljstva: Ivica Dragičević, Ivan Špalj i Filip Krišković te članovi nadzornog odbora: Stjepan Šojat, Drago Vlahović i Josip Zorko, a upisuju se novi članovi ravnateljstva: Josip Murković, Vladimir Parac, Petar Ostrman i Nikola Katalinić, poslovni ravnatelj Filip Krišković te članovi nadzornog odbora: Franjo Bezjak, Matija Moguš i Stipe Vukelić. ${ }^{75}$

\section{Poslovanje Senjske štedionice Senj}

Krajem 1920. čisti dobitak Senjske štedionice iznosio je $60.227 \mathrm{kruna}^{76}$, dok je krajem 1921. čisti dobitak iznosio 154.840 kruna. ${ }^{77}$

I 1926. poslovnu godinu, kao i proteklih godina, karakterizirala je privredna kriza. Neosporno je bilo da su državni tereti koji su nametani privredi bili preveliki i teško podnošljivi. Davanja i režijski troškovi bili su također nerazmjerno veliki te skoro nitko nije bio u stanju napredovati, povećati svoju glavnicu i svoj imetak uopće. Poslovne su prilike bile nepovoljne. Postojala je razlika između tečajne i kupovne vrijednosti dinara ${ }^{78}$ te se postavljalo pitanje je li

${ }^{75}$ HR-HDA-215. MDR NDH, dosje Senjske štedionice Senj, Izvadak iz trgovačkog registra Okružnog suda u Sušaku za Senjsku štedionicu u Senju od 19. studenoga 1938., kut. br. 305 .

${ }^{76}$ Compass, Finanzielles Jahrbuch Tschechoslovakei-Jugoslavien 1922, LV, II. Band, 1922, 1144.

${ }_{77}$ Compass, Finanzielles Jahrbuch Jugoslavien-Ungarn 1923, LVI, III. Band, 1923, 216.

${ }^{78}$ Zakonom o novcu Kraljevine Jugoslavije od 11. svibnja 1931. preciziralo se da je novčana jedinica u Kraljevini dinar (D). Vrijednost dinara odgovarala je vrijednosti težine 26,5 miligrama čistog zlata. Privilegiju izdavanja novčanica u Kraljevini imala je Narodna banka Kraljevine Jugoslavije. Kao primjer usporedbe vrijednosti dinara u odnosu na druge valute navodim tečajeve iz godine 1924. i 1941. Tečaj dinara koji je 25. prosinca 1923. odredio ministar financija, a koji je važio od 1. do 31. siječnja 1924. bio je sljedeći: 1 engleska funta $=385 \mathrm{D}, 1$ američki dolar $=88 \mathrm{D}$, 100 francuskih franaka $=460 \mathrm{D}, 100$ švicarskih franaka $=1.545 \mathrm{D}, 100$ talijanskih lira $=383 \mathrm{D}, 100$ austrijskih kruna $=0,124$ D. Usporedbe radi, tečaj dinara za mjesec ožujak 1941, koji je objavio 
riječ o krizi jugoslavenskog državnog aparata, valute, novca i kredita ili svega toga zajedno. U tom poremećenom privrednom mehanizmu dotada se najuspješnije opiralo baš bankarstvo kao najzdraviji i najjači, a svakako i najotporniji dio narodne privrede. Politika novčarskih zavoda ogledala se dotad u bilancama i dividendama, pa je mali dioničar tako i gledao na zavod: sa stajališta dividende. Već je 1925. godina kao posljedicu opće ekonomske krize kod svih novčarskih zavoda pokazivala poslovno opadanje. Ipak, za tu poslovnu godinu ti isti zavodi davali su velike dividende zbog svojega prestiža. Tako je npr. Jugoslavenska banka, kao tzv. Velebanka, platila u toj godini za poreze i dividende 23,000.000 dinara, dok je njezina dionička glavnica iznosila 100.000.000 dinara, što je svakako bilo nerazmjerno. Primjer velebanaka slijedili su provincijalni zavodi te su prema svojim prilikama dijelili razmjerno visoke dividende. Ravnateljstvo Senjske štedionice polazilo je od gledišta da prvenstveno treba očuvati zavod, što je i učinjeno. Godine 1926. stanje blagajne Senjske štedionice iznosilo je $56.323,36$ dinara, stanje uloga 1,317.018,35 dinara, stanje predujmova na vrijednosne stvari 2.977,70 dinara, stanje mjenične lisnice 1,364.203,75 dinara, stanje poslovnih prijatelja (dužnici) 1,723.761,88 dinara, ustupljene mjenice 252.905 dinara, a čisti dobitak 2.925,50 dinara. ${ }^{79}$

Prema podacima Komorskoga ureda u Senju, najvažnije su senjske drvne tvrtke bile: Grga Ratković, Juraj Krmpotić, Viktor Benzia, Juraj Tićak, Eugen Scarpa, Jure Biondić i M. Rogić. Prve tri bile su okupljene oko Senjske štedionice, dok su ostale obavljale svoje poslove putem podružnice Prve hrvatske štedionice u Senju. ${ }^{80}$

ministar financija 28. veljače 1941. bio je slijedeći: 1 engleska funta $=217,50 \mathrm{D}, 1$ američki dolar $=55 \mathrm{D}, 100$ francuskih franaka $=119 \mathrm{D}, 100$ švicarskih franaka $=1.276 \mathrm{D}, 100$ talijanskih lira $=$ 228,80 D, 1 njemačka marka = 17,82 D, 1 kanadski dolar = 54 D. Vidi: S. LAJNERT, 2015, 126. Da bismo shvatili kupovnu vrijednost dinara u Kraljevini Jugoslaviji te je usporedili sa stvarnom vrijednošću kapitala štedionice, pogledajmo kao primjer cijene nekih živežnih namirnica iz 1932. godine: $100 \mathrm{~kg}$ raži 100 dinara, $100 \mathrm{~kg}$ ječma 100 dinara, $100 \mathrm{~kg}$ bijelog brašna za luksuzna peciva 300 dinara, $100 \mathrm{~kg}$ kukuruznog brašna 90 dinara, $100 \mathrm{~kg}$ krumpira 60 dinara, $100 \mathrm{~kg}$ krupnog graha tetovca 250 dinara, 100 kg grožđa 200 dinara, 1 komad žive kokoši 10 dinara, sanduk od 1440 komada svježih jaja 900 dinara, 1 komad svinje do $70 \mathrm{~kg} 350$ dinara. Vidi Cenovnik po kome će se vršiti obezbeđenje valute pri izvozu robe po čl. 6. Pravilnika o regulisanju prometa devizama i valutama od 7. listopada 1931. (važi od 1. do 29. veljače 1932.), Narodne novine. Službeni list Savske banovine, br. 26, 2. veljače 1932., 6.

${ }^{79}$ HR-HDA-215. MDR NDH, dosje Senjske štedionice Senj, Izvještaj ravnateljstva Senjske štedionice za glavnu skupštinu od 12. lipnja 1927.; Račun razmjere od 31. prosinca 1926., kut. br. 305 .

${ }^{80}$ HR-HDA-215. MDR NDH, dosje Senjske štedionice Senj, Izvještaj o pregledu Senjske štedionice od 26. srpnja 1927., kut. br. 305. 
Prema izvješću o nadzoru i reviziji štedionice od 26. srpnja 1927. doba poslijeratne konjukture iskoristilo je vodstvo štedionice za povišenje glavnice i vlastitih sredstava, ali nije znalo unaprijediti interese zavoda. Cijeli niz nepromišljenih, neuspjelih trgovačkih poslova i raznih angažmana prouzročili su da je Senjska štedionica izgubila i imobilizirala znatan dio svojih vlastitih sredstava za nekoliko godina. Zbog ovoga poslovnog neuspjeha izgubila je povjerenje na tržištu, a to ju je primoralo da vrati polovicu povjerenih joj uloga ${ }^{81}$ Krajem 1927. čisti dobitak Senjske štedionice iznosio je 3.829 dinara. ${ }^{82}$

Dana 2. travnja 1929. komesari Ministarstva trgovine i industrije izvršili su nadzor nad radom i stanjem Senjske štedionice. Komesari su konstatirali da se zavod, osim svojih pravilima predviđenih poslova, bavio i izdavanjem garantnih pisama, za što nije bio ovlašten. Dionički kapital od 1,125.000 dinara bio je formalno uplaćen i sav je bio u domaćim rukama. Glavni su dioničari bili: Milan Prpić i obitelj (7.800 dionica ${ }^{83}$ ), Grga Ratković (1.374 dionica), obitelj Dragičević (1.168 dionica), obitelj Franceschini (1.050 dionica), obitelj Krmpotić (1.050 dionica), obitelj Vlahović (1.020 dionica), obitelj Rukavina (530 dionica), Viktor Benzia (465 dionica), Josip Geržanić (453 dionica), Milan Brajković (450 dionica) i Juraj Mladineo (412 dionica). Zavod je dobio kredit od Narodne banke u visini od 225.000 dinara za koji je plaćao 6\% kamate, a kao garancija za taj kredit uknjižena je bila Narodna banka na zavodsku zgradu za 300.000 dinara. Nadalje, zavod je dobio kod Prve hrvatske štedionice kredit od 100.000 dinara za koji je plaćao $16 \%$. Oba navedena kredita zavod je iskorištavao reeskontom mjenica. Od svojih dužnika štedionica je naplaćivala 8-20\% kamata, a na uloge je plaćala interes između 4-8\%. ${ }^{84}$

Krajem 1929. čisti dobitak Senjske štedionice iznosio je 4.314 dinara. ${ }^{85}$

Krajem 1937. godine gotovina u blagajni iznosila je 83.686,70 dinara, stanje mjenica 959.231,89 dinara, dužnici po tekućem računu 1,790.509,35 dinara, vjerovnici po tekućem računu 909.469,66 dinara, ulozi na knjižicama 724.602,85 dinara, reeskont 413.660 dinara. Čisti dobitak štedionice u 1937.

${ }^{81}$ HR-HDA-215. MDR NDH, dosje Senjske štedionice Senj, Izvještaj o pregledu Senjske štedionice od 26. srpnja 1927., kut. br. 305.

${ }^{82}$ Compass, Finanzielles Jahrbuch Jugoslavien 1929, LXII, 1929, 273.

${ }^{83}$ Obitelj Prpić uistinu je posjedovala 10.233 komada dionica, no vlasništvo daljnjih 2.433 dionica nije se iz knjige dioničara moglo konstatirati jer očito još nisu bile prenesene.

${ }^{84}$ HR-HDA-215. MDR NDH, dosje Senjske štedionice Senj, Izvještaj o pregledu rada i stanja Senjske štedionice u Senju od 2. travnja 1929., kut. br. 305.

${ }^{85}$ Compass, Finanzielles Jahrbuch Jugoslavien 1931, LXIV, 1931, 381. 
iznosio je 17.631,18 dinara, što je s prijenosom dobitka iz ranijih godina od 9.220,48 dinara iznosilo 26.851,66 dinara. ${ }^{86}$

Opća privredna situacija u svijetu te u Kraljevini Jugoslaviji 1938., pored sve političke napetosti u međunarodnim odnosima, opravdavala je u punoj mjeri nadu da će ekonomski razvoj življom poslovnom djelatnošću krenuti na bolje te će dovesti do privrednoga ozdravljenja. Međutim, te nade nisu se ostvarile. Za vrijeme trajanja agrarne i kreditne $\mathrm{krize}^{87}$ nije bilo privrednoga poboljšanja. Ravnateljstvo Senjske štedionice je, uz ostalo poslovanje, vodilo brigu i o dubioznim potraživanjima ${ }^{88}$, koja su datirala iz poslovanja od 1925. do 1932. godine te je osnovalo specijalnu rezervu za takva potraživanja. Tu je rezervu dotirao "Račun Pričuvne zaklade" s iznosom od 167.453,77 dinara i "Račun čistog dobitka" s iznosom od 26.851,66 dinara ili s ukupno 194.305,43 dinara. Ravnateljstvo je isto tako predvidjelo u aktivi pod stavkom "Dubiozna potraživanja" iznos od 194.305,43 dinara od potraživanja štedionice protiv Jurja Krmpotića, koji je u međuvremenu i preminuo, kao otpis u poslovnoj godini 1939. Zahvaljujući podružnici Jugoslavenske udružene banke d.d. na Sušaku, Senjska štedionica je i u poslovnoj 1938. godini mogla svojim komitentima staviti na raspolaganje potreban iznos gotovine. Naime, navedena banka podupirala je štedionicu pružajući joj izvjesne kredite za kratkoročne poslove. Također, Narodna banka Kraljevine Jugoslavije povisila je štedionici dotadašnju reeskontnu vjeresiju na 500.000 dinara. U poslovnoj 1938. godini Senjska štedionica uskladila je svoju obrtnicu s propisima Ministarstva trgovine i industrije, pa se na temelju nje mogla baviti svim bankovnim poslovima. Poslovanje štedionice u 1938. godini kretalo se u znaku napredovanja, pa je njezin promet iznosio 55,403.132,28 dinara. Krajem 1938. godine gotovina u blagajni iznosila je 38.109,91 dinara, stanje mjenica 927.269 dinara, dužnici po tekućem računu 2,054.322,77 dinara, vjerovnici po tekućem računu 1,090.914,11 dinara, ulozi na knjižicama 1,013.249,54 dinara, reeskont 289.365 dinara. Čisti

${ }^{86}$ HR-HDA-152. SFD, dosje Senjske štedionice Senj, Poziv ravnateljstva Senjske štedionice od 28. travnja 1938. na LXV. redovitu glavnu skupštinu koja se održala 22. svibnja 1938., kut. br. 260.

${ }^{87} \mathrm{O}$ bankovno-novčarskom sustavu u Hrvatskoj, o svjetskoj ekonomskoj krizi iz 1931. te o njenom utjecaju na taj sustav opširnije vidi: J. TOMAŠEVIĆ, 1938; M. KOLAR-DIMITRIJEVIĆ, 2013; S. LAJNERT, 2008. Značajan izvor za istraživanje te analizu utjecaja društveno-ekonomskih prilika na bankovno-novčarski sustav, a napose na pojedinačne novčarske zavode predstavljaju godišnja poslovna izvješća novčarskih zavoda napisana za glavne skupštine dioničara. Vidi: HRHDA-152. SFD i HR-HDA-215. MDR NDH.

${ }^{88}$ Dubióza lat. (dubius - sumnjiv) sumnjiva potraživanja (ali se još uvijek ne smatraju nenaplativima). Vidi: B. KLAIĆ, 2001, 328. 
dobitak štedionice iznosio je $22.608,03$ dinara ${ }^{89} \mathrm{Od}$ ukupno 25.489,08 dinara režijskih troškova u 1938. godini za milodare je utrošeno 930 dinara. $^{90}$ Vrijednost vlastitih nekretnina iznosila je 470.000 dinara, od toga 1. dvokatnica u gradu Senju, Jurišićeva ulica br. $62 \quad(260.000$ dinara $)$ s namještajem $\quad(30.000$ dinara), 2. trokatnica u gradu Senju, Paskvićeva ulica br. 160 (150.000 dinara) s namještajem (25.000 dinara), 3. zemljište "Novi Svit" u gradu Senju na morskoj obali (5.000 dinara).${ }^{91}$ Prihod vlastitih nekretnina (najamni brutto dohodak) iznosio je

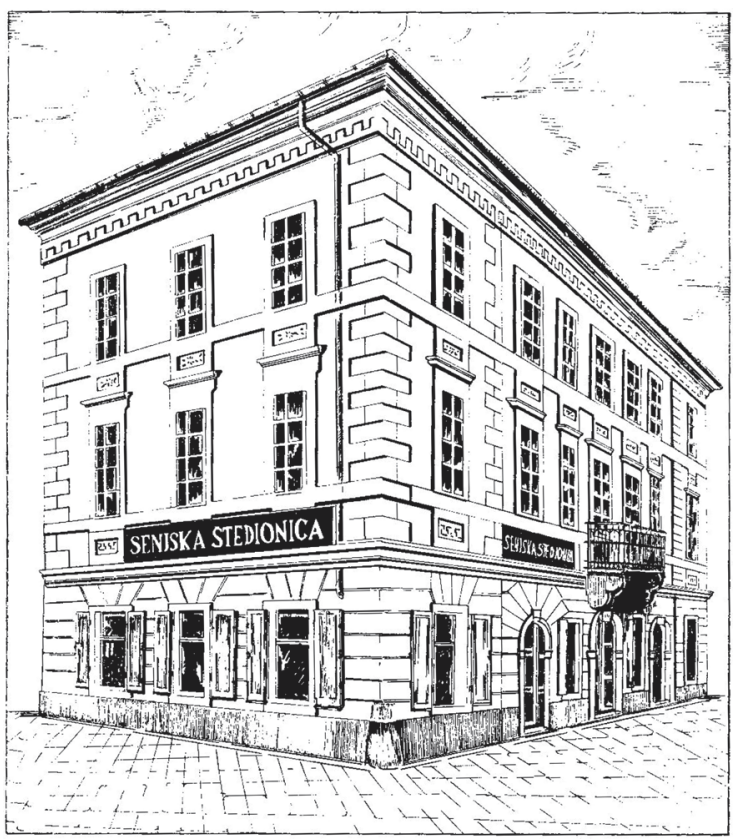

S1. 1. Zgrada Senjske štedionice Senj u Jurišićevoj ulici br. $62^{93}$

28.385 dinara, od toga: za kuću u Jurišićevoj ulici br. 62 (12.720 dinara) i za kuću u Paskvićevoj ulici br. 160 (15.665 dinara). ${ }^{92}$

Opće prilike u 1939. godini nisu bile nimalo povoljne. Velike promjene u centralnoj Europi donijele su kao posljedicu razne perturbacije u čitavom svijetu tako da su zapadne sile navijestile rat Njemačkoj. Zbog toga su međunarodne trgovačke veze kod svih naroda bile otežane, bez obzira na zauzimanje neutralnoga stava. U te zemlje ubrajala se i Kraljevina Jugoslavija.

${ }^{89}$ HR-HDA-152. SFD, dosje Senjske štedionice Senj, Izvještaj ravnateljstva Senjske štedionice o poslovanju za 1938. godinu, 15. lipnja 1939.; Poziv ravnateljstva Senjske štedionice od 31. svibnja 1939. na LXVI. redovitu glavnu skupštinu koja se održala 18. lipnja 1939., kut. br. 260 .

${ }^{90}$ HR-HDA-152. SFD, dosje Senjske štedionice Senj, Iskaz režijskih troškova za god. 1938., kut. br. 260.

${ }^{91}$ HR-HDA-152. SFD, dosje Senjske štedionice Senj, Izvadak računa vlastitih nekretnina per 31. XII. 1938.; Poziv ravnateljstva Senjske štedionice od 31. svibnja 1939.. na LXVI. redovitu glavnu skupštinu koja se održala 18. lipnja 1939., kut. br. 260.

${ }^{92}$ HR-HDA-152. SFD, dosje Senjske štedionice Senj, Iskaz prihoda vlastitih nekretnina u god. 1938., kut. br. 260. 


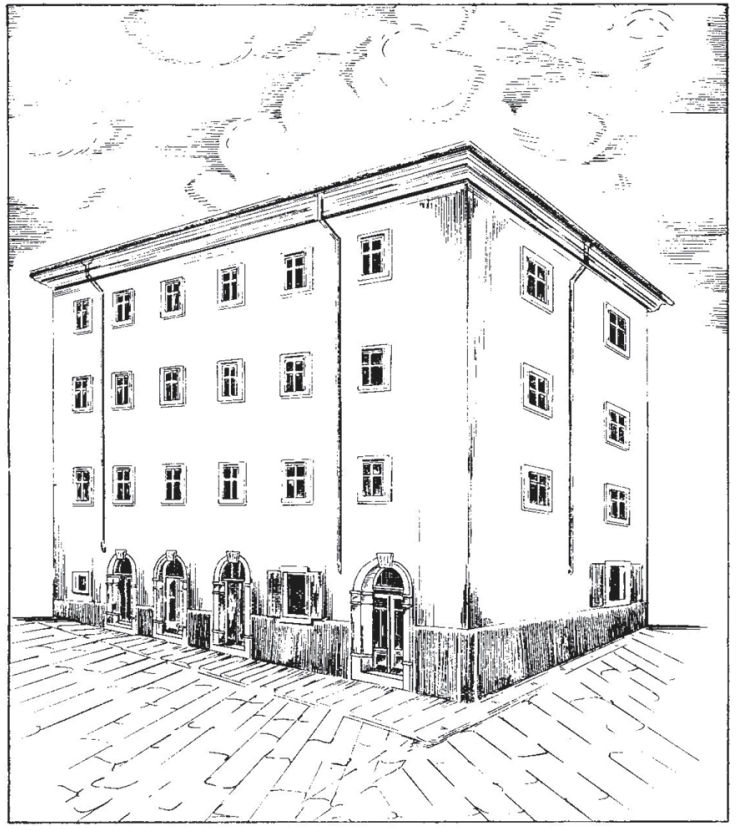

S1. 2. Zgrada Senjske štedionice Senj u Paskvićevoj ulici br. $160^{94}$

Iako je Jugoslavija ostala neutralna, nije izbjegla posljedicama ratnog stanja zbog toga što je žrtvovala velike iznose za svoju obrambenu spremnost, kojaje iziskivala velika opterećenja privrede s novim nametima i porezima. Zbog toga je došlo do poskupljenja svih životnih namirnica (potreba), ograničenja u prometu i trgovini, oskudice robe koja se uvozila, povišenja poreza, uz neizostavnu nesigurnost $\mathrm{i}$ neizvjesnost.

$\begin{array}{ccr}\text { Iako } & \text { su u } & 1939 . \\ \text { godini, } & \text { prema } & \text { viđenju }\end{array}$
ravnateljstva štedionice, uistinu bile dvije bankovne krize, Senjska štedionica ih je s lakoćom prebrodila. Kao i do tada, štedionica je izlazila u susret svojim poslovnim prijateljima odobravanjem brojnih novih kredita. Štedionica je svoj rad prilagođavala prilikama kako bi što bolje poslužila poslovnom svijetu te uspješno sačuvala stečeno povjerenje poslovnih prijatelja. Da je Senjska štedionica godine 1939. mogla udovoljiti zahtjevima svojih poslovnih prijatelja, svakako je zasluga i njezinih bankovnih veza - podružnica Sušak Narodne banke Kraljevine Jugoslavije te podružnica Sušak Jugoslavenske udružene banke. Poslovanje štedionice je i u 1939. godini pokazivalo znakove napredovanja, pa je tako čisti dobitak za tu godinu iznosio 30.123,31 dinara. Od toga iznosa trebalo je dotirati Specijalni fond za rezerve sa 10\%, tj. sa 3.012,31 dinara. S tim iznosom trebalo je nabaviti vrijednosne papire, pa je nakon toga ostao čisti dobitak za prijenos na poslovnu godinu 1940. od 27.111 dinara. S prijenosom dobitka iz 1938. godine od 20.348,03 dinara, dobitak je iznosio

${ }^{93}$ Izvor skice: HR-HDA-152. SFD, dosje Senjske štedionice Senj, poziv ravnateljstva Senjske štedionice od 14. travnja 1940. na LXVII. redovitu glavnu skupštinu, kut. br. 260.

${ }^{94}$ Izvor skice: HR-HDA-152. SFD, dosje Senjske štedionice Senj, poziv ravnateljstva Senjske štedionice od 14. travnja 1940. na LXVII. redovitu glavnu skupštinu, kut. br. 260. 
ukupno 47.459,03 dinara. ${ }^{95}$ Krajem 1939. godine gotovina u blagajni iznosila je 80.133,79 dinara, stanje mjenica 1,508.543,35 dinara, dužnici po tekućem računu 2,809.750,31 dinara, vjerovnici po tekućem računu 1,969.802,29 dinara, ulozi na knjižicama 1,266.973,32 dinara, reeskont 499.000 dinara. Kod Senjske štedionice, kao malog novčarskog zavoda, još uvijek se nije mogla pokazati neka osobito čista dobit jer se ona koristila kreditima jačih novčanih zavoda, kojima je za te kredite morala plaćati visoke kamate. Također, štedionica je imala i velike troškove oko nabave takvih kredita, a prema Uredbi o maksimiranju kamata ${ }^{96}$ od 22. studenoga 1933. nije mogla zaračunavati više kamate od $10 \%$, pa je iskazani dobitak itekako zadovoljavao. S obzirom na to da je Senjska štedionica znala cijeniti potrebe grada Senja i okolice, njezino ravnateljstvo zamolilo je sve one kojima je ona bila pri srcu da podupru njihova nastojanja za njezin napredak. ${ }^{97}$ Režijski troškovi štedionice u 1939. godini iznosili su sveukupno 39.020,12 dinara, od čega je za ogrjev potrošeno 2.122 dinara, kancelarijski pribor 17.793,75 dinara, najamne priznanice dane strankama 1.110 dinara, poštanske marke za poštarinu 8.893,87 dinara, razne biljege na priznanice i knjige 1.835,50 dinara, novine 1.500 dinara (od toga Narodne novine 300 dinara, Jugoslavenski Lloyd 440 dinara, Poreski pregled

${ }_{95}$ Prema bilanci Senjske štedionice na dan 31. prosinca 1939., čisti dobitak za 1939. iznosio je 30.123,31 dinara (s prijenosom dobitka iz 1938. godine od 20.348,03 dinara, iznosio je ukupni dobitak 50.471,34 dinara). Kada se uplatilo Specijalni fond za rezerve u iznosu od 3.012,31 dinara, dobitak je uistinu iznosio 47.459,03 dinara.

${ }^{96}$ Uredba o maksimiranju kamata donesena je 22. studenoga 1933. Novčarski zavodi na području svake banovine bili su dužni u roku od mjesec dana od dana stupanja na snagu ove Uredbe utvrditi najvišu kamatnu stopu na posuđeni novac. Kamata za posuđeni novac mogla je biti najviše za 5\% veća od eskontne stope Narodne banke. Zavodi su mogli utvrditi istu kamatnu stopu za cijelu banovinu ili razne stope za pojedine dijelove banovine i za pojedine vrste zavoda, kao što su bile dioničke banke, štedionice, privredne kreditne zadruge i dr. Kamata na uloge koji su primali novčarski zavodi nije mogla biti veća od eskontne stope Narodne banke smanjene za $1 \%$. Pod novčarskim zavodima u smislu ove Uredbe podrazumijevane su novčarske ustanove koje su bile osnovane kao dionička društva ili kao društva s ograničenom odgovornošću ili kao kreditne privredne zadruge, zatim štedionice samoupravnih tijela i udruženja, kao i one novčarske ustanove koje su bile osnovane po zakonima donesenim za svaku od njih posebno. Ako je novčarski zavod platio veću kamatu na ulog od one koju je propisivala ova Uredba, bio je novčano kažnjen od ministra trgovine i industrije do 50.000. - dinara. Sume naplaćene po ovim kaznama unesene su u fond za nadzor nad novčarskim zavodima. Vidi: Službene novine Kraljevine Jugoslavije, br. 278, 4. prosinca 1933, 1527-1528. Također, vidi: S. LAJNERT, 2015, 130.

${ }^{97}$ HR-HDA-152. SFD, dosje Senjske štedionice Senj, Izvještaj ravnateljstva Senjske štedionice o poslovanju za 1939. godinu, 27. travnja 1940.; Poziv ravnateljstva Senjske štedionice od 14. travnja 1940. na LXVII. redovitu glavnu skupštinu koja se održala 5. svibnja 1940., kut. br. 260. 
240 dinara, Narodno blagostanje 280 dinara i Obzor 240 dinara), rasvjetu poslovnih prostorija 1.893 dinara, telefonske razgovore 2.895 dinara i milodare prosjacima 977 dinara. ${ }^{98}$

Za usporedbu spomenimo poslovanje nekoliko drugih štedionica u 1939. godini. Tako je, primjerice, Novogradiška štedionica d.d. Nova Gradiška imala dioničku glavnicu od 1,000.000 dinara, a dobitak od 37.025,53 dinara. ${ }^{99}$ Pučka dionička štediona Nova Gradiška imala je dioničku glavnicu od 1,000.000 dinara, a dobitak od 6.076,35 dinara. ${ }^{100}$ Zelinska dionička štediona Sv. Ivan Zelina imala je temeljnu dioničku glavnicu od 200.000 dinara i prvenstvenu dioničku glavnicu od 500.000 dinara, a čisti gubitak od 97.899,74 dinara. ${ }^{101}$ Samoborska štedionica Samobor imala je dioničku glavnicu od 400.000 dinara, a gubitak od 17.564,13 dinara. ${ }^{102}$ Hrvatska katolička štediona d.d. Nova Gradiška imala je dioničku glavnicu od 250.000 dinara, a dobitak od 137.091,36 dinara. ${ }^{103}$ Pučka štedionica d.d. Jastrebarsko imala je dioničku glavnicu od 100.000 dinara, a gubitak od 86.639,57 dinara. ${ }^{104}$ Jastrebarska dionička štedionica Jastrebarsko imala je dioničku glavnicu od 240.000 dinara, a ukupni gubitak od 16.381,53 dinara. ${ }^{105}$ Našička štedionica Našice imala je dioničku glavnicu od 150.000 dinara, a gubitak od 24.266,89 dinara. ${ }^{106}$ Preloška štedionica d.d. Prelog imala je dioničku glavnicu od 300.000 dinara, a gubitak u 1939. godini 10.534,54 dinara (s prijenosom gubitka iz 1938. u iznosu od 89.174,12 dinara, ukupni gubitak iznosio je 99.708,66 dinara). ${ }^{107}$ Od velebanaka, Prva hrvatska štedionica Zagreb

${ }^{98}$ HR-HDA-152. SFD, dosje Senjske štedionice Senj, Iskaz režijskih troškova za posl. god. 1939., kut. br. 260.

${ }^{99}$ Razmjera Novogradiške štedionice d.d. Nova Gradiška za godinu 1939, Narodne novine. Službeni list Banovine Hrvatske, br. 53, 5. ožujka 1940, 4.

${ }^{100}$ Razmjera Novogradiške štedionice d.d. Nova Gradiška za godinu 1939, Narodne novine. Službeni list Banovine Hrvatske, br. 53, 5. ožujka 1940., 4.

${ }^{101}$ Račun razmjere Zelinske dioničke štedione Sv. Ivan Zelina za godinu 1939, Narodne novine. Službeni list Banovine Hrvatske, br. 55, 7. ožujka 1940., 4.

${ }_{102}$ Bilanca Samoborske štedionice Samobor za godinu 1939, Narodne novine. Službeni list Banovine Hrvatske, br. 59, 12. ožujka 1940., 4.

${ }^{103}$ Račun razmjere Hrvatske katoličke štedione d.d. Nova Gradiška dne 31. prosinca 1939, Narodne novine. Službeni list Banovine Hrvatske, br. 63, 16. ožujka 1940., 4.

${ }^{104}$ Razmjera Pučke štedionice d.d. Jastrebarsko za poslovnu 1939, Narodne novine. Službeni list Banovine Hrvatske, br. 93, 24. travnja 1940., 5.

${ }^{105}$ Razmjera Jastrebarske dioničke štedionice Jastrebarsko za godinu 1939, Narodne novine. Službeni list Banovine Hrvatske, br. 93, 24. travnja 1940., 6.

${ }^{106}$ Račun razmjere Našičke štedionice Našice 31. prosinca 1939, Narodne novine. Službeni list Banovine Hrvatske, br. 103, 8. svibnja 1940., 4.

${ }^{107}$ Razmjera Preloške štedionice d.d. Prelog za godinu 1939, Narodne novine. Službeni list Banovine Hrvatske, br. 106, 11. svibnja 1940., 6. 
imala je dioničku glavnicu od 75,000.000 dinara, a dobitak od 6,729.954,46 dinara (odbivši dotacije Pričuvnoj zakladi, novom poslovanju i pričuvi za porez, iznosio je dobitak 5,729.954,46 dinara). ${ }^{108}$

Sama poslovna 1940. godina bila je u znaku ratnih sukoba. Takve prilike prouzročile su velike poteškoće u međunarodnim odnosima, koje su pogodile i Kraljevinu Jugoslaviju. Najviše je to osjetio privredni život. U takvim prilikama najvažniji je problem bio namaknuti novčana sredstva kako bi privreda mogla izdržati i uspješno poslovati. To je Senjska štedionica postigla uz raznu pomoć te je uspjela omogućiti svojim poslovnim prijateljima odvijanje već započetih poslova, koje su oni, uz obostrano zadovoljstvo, i završili. Ukupni promet u 1940. godini iznosio je 100.609.859,07 dinara. Krajem 1940. godine gotovina u blagajni iznosila je 131.202,90 dinara, stanje mjenica 1,271.377,25 dinara, dužnici po tekućem računu 3,261.884,44 kuna, ulozi po knjižicama 1,264.531,70 dinara, reeskont 499.000 dinara. Čisti dobitak u 1940. godini iznosio je 32.226,50 dinara, od kojeg iznosa je trebalo dotirati sa $10 \%$ Specijalni fond za rezerve, odnosno sa 3.222,65 dinara. Tim iznosom trebalo je nabaviti vrijednosne papire, pa je nakon toga ostao čisti dobitak od 29.003,85 dinara. Krajem 1940. dionička glavnica iznosila je i nadalje $1,125.000$ dinara. ${ }^{109}$

Analizom poslovanja štedionice u Kraljevini Srba, Hrvata i Slovenaca/ Jugoslaviji vidljivo je da je ona, za razliku od većeg broja štedionica koje su poslovale s gubitkom, prebrodila veliku svjetsku ekonomsku krizu te nastavila s uspješnim, makar i skromnim pozitivnim poslovanjem. Čak je i značajno povećala svoju dioničku glavnicu na 1,125.000 dinara. Iako je prema mišljenju ravnateljstva Senjske štedionice ona spadala pod male novčarske zavode, možemo zaključiti da je, s obzirom na svoju dioničku glavnicu i konstantno poslovanje s dobitkom, Senjska štedionica postala značajnijim lokalnim novčarskim zavodom.

\section{Djelovanje Senjske štedionice Senj u Nezavisnoj Državi Hrvatskoj}

Prema izvješću ravnateljstva Senjske štedionice od 28. studenoga 1941., Nezavisna Država Hrvatska stajala je pred velikim zadacima. U očekivanju jakoga općeg poleta ravnateljstvo Senjske štedionice moralo je misliti na

${ }^{108}$ Razmjera Prve hrvatske štedionice Zagreb 31. prosinca 1939., Narodne novine. Službeni list Banovine Hrvatske, br. 61, 14. ožujka 1940., 4. Osim dioničke glavnice od 75,000.000 dinara u računu razmjere spominje se i prvenstvena dionička glavnica (novo poslovanje) od 20,000.000 dinara.

${ }^{109}$ HR-HDA-215. MDR NDH, dosje Senjske štedionice Senj, Izvješće ravnateljstva Senjske štedionice za glavnu skupštinu, 28. studenoga 1941., ur.br. 14.689/1941., kut. br. 305. 
povećanje obrtnog kapitala, koji se mogao namaknuti ili stalnim ulozima poslovnih suradnika ili povećanjem dioničke glavnice. Bezuvjetna je zadaća novoga ravnateljstva uz ostale poslove u 1941. i 1942. godini bila da provede povišenje dioničke glavnice barem do 2,000.000 kuna ${ }^{110}$, izdanjem 17.500 komada dionica po 50 kuna. To izdanje dozvoljeno je već navedenom odlukom Kotarskog suda u Senju od 2. siječnja 1924. pod br. 3.000 gr.R.70/1906. Ravnateljstvo Senjske štedionice po tome pitanju apeliralo je na sve prijatelje zavoda da im u tome pomognu. ${ }^{111}$

${ }^{110}$ Zakonskom odredbom o novcu Nezavisne Države Hrvatske od 7. srpnja 1941. uvodi se novčana jedinica kuna (Kn) koja se dijeli na 100 banica (b). Vrijednost jedne kune odgovarala je vrijednosti od 17,921 miligrama $(0,017921$ grama) čistoga zlata. Tom odredbom ovlaštena je Hrvatska državna banka da zamijeni dinarske novčanice bivše Narodne banke Kraljevine Jugoslavije novim novčanicama, koje su od 26. svibnja 1941. nosile potpis ministra narodnog gospodarstva Lovre Sušića. Dinarske novčanice zamijenila je Hrvatska državna banka novim državnim novčanicama u jednakoj naslovnoj (nominalnoj) vrijednosti bez ikakvih odbitaka. Kao primjer usporedbe vrijednosti kune u odnosu na druge valute, navodim tečajeve iz godine 1941. i 1944. Tečaj kune koji je po odredbi državnog rizničara 29. kolovoza 1941. odredio pročelnik Odjela za državnu imovinu, navjeru i dugove, a koji je bio na snazi od 1. do 30. rujna 1941. bio je sljedeći: 1 njemačka marka $=20 \mathrm{Kn}, 1$ američki dolar $=50 \mathrm{Kn}, 1$ kanadski dolar $=50 \mathrm{Kn}, 1$ engleska funta $=$ $200 \mathrm{Kn}, 100$ talijanskih lira $=263,15 \mathrm{Kn}, 100$ švicarskih franaka $=1.159 \mathrm{Kn}, 100$ francuskih franaka = Kn 100 Kn. Službeni tečaj kune za listopad 1944., koji je objavilo Ministarstvo državne riznice, Odjel za novčarstvo, državnu imovinu i dugove od 30. rujna 1944., bio je sljedeći: 1 njemačka marka $=20 \mathrm{Kn}, 100$ talijanskih lira $=200 \mathrm{Kn}, 100$ švicarskih franaka $=1.159 \mathrm{Kn}, 100$ francuskih franaka $=100 \mathrm{Kn}, 100$ srpskih dinara $=100 \mathrm{Kn}$. Vidi: S. LAJNERT, 2015, 158-159. Da bi smo shvatili realnu vrijednost kune te je usporedili sa stvarnom vrijednošću kapitala štedionice, spomenimo da je otkupna cijena cikorijine repe za 1942. iznosila 180 kuna za $100 \mathrm{~kg}$, otkupna cijena divljeg kestena za tov svinja iznosila je 50 banica za $1 \mathrm{~kg}$. Na zagrebačkom godišnjem Margaretskom sajmu cijene stoke bile su sljedeće: stoka za klanje i tov: bikovi I. vrste $19 \mathrm{kn}$ po $\mathrm{kg}$, volovi I. vrste 19,50 kn po $\mathrm{kg}$, odojci 1.000-1.400 kn po komadu; stoka za hranu: volovi mršavi 14.000-16.000 kuna, junci i junice 12.000 kuna, krave 14.000-16.000 kuna, ovce 8.000-10.000 kuna, konji za uzgoj i rasplod: pastusi 30.000-50.000 kuna, kobile 26.000-40.000 kuna, ždrebad laka 12.000-15.000 kuna, ždrebad teška 15.000-20.000 kuna, konji za rad: laki 14.000-30.000 kuna, srednji 16.000-35.000 kuna, teški 18.000-50.000 kuna. Dana 16. srpnja 1942. u Zagrebu su cijene voća i povrća bile sljedeće: blitva $15 \mathrm{kuna}$ po $\mathrm{kg}$, bob 20 kuna po kg, jestive buće 15 kuna po kg, celer 40 kuna po kg, cikla 15 kuna po kg, grah u mahunama bez niti 30 kuna po kg, grašak obični 25 kuna po kg, hren 20 kuna po kg, kelj 15 kuna po kg, mladi krumpir 20 kuna po kg, zeleni kupus 15 kuna po kg, bijeli luk 30 kuna po $\mathrm{kg}$, mlada mrkva 18 kuna po kg, peršin 20 kuna po kg, crvena rajčica 50 kuna po kg, špinat $40 \mathrm{kuna}$ po $\mathrm{kg}$, borovnice $15 \mathrm{kuna}$ po $\mathrm{kg}$, breskve I. vrste 60 kuna po $\mathrm{kg}$, jabuke za ukuhavanje I. vrste 40 kuna po kg, šumske jagode 25 kuna po litri, kruške 30-40 kuna po kg, maline 30 kuna po litri, ribiz 25 kuna po litri, trešnje I. vrste 30 kuna po kg, višnje I. vrste 35 kuna po kg. Na križevačkom sajmu maslac se prodavao od 120-150 kuna po kg, a jaja 3-4 kune po komadu. Vidi: Gospodarski list, br. 30, 23. srpnja 1942., 7-8, 13-14.

${ }^{111}$ HR-HDA-215. MDR NDH, dosje Senjske štedionice Senj, Izvješće ravnateljstva Senjske štedionice za glavnu skupštinu, 28. studenoga 1941., ur.br. 14.689/1941., kut. br. 305. 
Dana 30. studenoga 1941. održana je redovita glavna skupština dioničara Senjske štedionice na kojoj su izabrani članovi uprave. U ravnateljstvo su izabrani dr. Ante Lončarić, Viktor Benzia, mr. ph. Jerko Dominis, dr. Ante Vlahović, Petar Šimatić, Petar Ostrman, Josip Murković, Vladimir Parac, Karlo Mladineo, Juraj Brlečić i Milan Brajković. U nadzorni odbor izabrani su Franjo Bezjak, Matija Moguš, Stipe Vukelić, prof. Jakov Čanić i Josip Antić. Zamjenici članova nadzornog odbora bili su Ivan Mihovilić i Anton Vrhovac. ${ }^{112}$

31. prosinca 1941. temeljna dionička glavnica Senjske štedionice iznosila je 1,125.000 kuna, a dobitak 10.023,07 kuna. ${ }^{113} \mathrm{Za}$ usporedbu spomenimo poslovanje nekoliko drugih štedionica u 1941. godini. Tako je, primjerice, Novogradiška štedionica d.d. Nova Gradiška imala dioničku glavnicu od 1,000.000 kuna, a dobitak od 24.409 kuna. Pučka dionička štediona Nova Gradiška imala je dioničku glavnicu od 1,000.000 kuna, a dobitak od 508.830 kuna. Zelinska dionička štediona Sv. Ivan Zelina imala je dioničku glavnicu od 1,000.000 kuna (od toga uplaćeno 700.000 kuna), a gubitak od 293.285 kuna. Samoborska štedionica Samobor imala je dioničku glavnicu od 400.000 kuna, a gubitak od 36.687 kuna. Hrvatska katolička štediona d.d. Nova Gradiška imala je dioničku glavnicu od 250.000 kuna, a dobitak od 137.562 kuna. Pučka štedionica d.d. Jastrebarsko imala je dioničku glavnicu od 100.000 kuna, a gubitak od 71.943 kuna. Jastrebarska dionička štedionica Jastrebarsko imala je dioničku glavnicu od 240.000 kuna, a gubitak od 57.082 kuna. Našička štedionica Našice imala je dioničku glavnicu od 150.000 kuna, a gubitak od 60.905 kuna. Od velebanaka, Prva hrvatska štedionica Zagreb imala je dioničku glavnicu od 200,000.000 kuna (od toga uplaćeno 95,000.000 kuna), a dobitak od 11,615.932 kuna. Od većih banaka spomenimo i Trgovačko industrijalnu banku d.d. Zagreb (prije Srpska banka d.d. Zagreb) koja je imala dioničku glavnicu od 60,000.000 kuna (od toga uplaćeno 47,000.000 kuna) te dobitak od 10,656.558 kuna. ${ }^{114}$

Prema podacima Senjske štedionice od 7. studenoga 1942., zavod nikada nije uživao nikakve zaštitne mjere niti mu je ikada bio postavljen povjerenik. ${ }^{115}$

${ }^{112}$ HR-HDA-215. MDR NDH, dosje Senjske štedionice Senj, Zapisnik LXVIII. redovite glavne skupštine dioničara Senjske štedionice od 30. studenoga 1941., ur.br. 14.689/1941., kut. br. 305 .

${ }^{113}$ Poziv na LXIX. redovitu glavnu skupštinu dioničara Senjske štedionice u Senju od 2. prosinca 1942., Narodne novine. Službeni list Nezavisne Države Hrvatske, br. 280, 10. prosinca 1942, 8. Vidi i: Compass, Finanzielles Jahrbuch Kroatien-Serbien 1943, 76, $1943,124$.

${ }^{114}$ Compass, Finanzielles Jahrbuch Kroatien-Serbien 1943, 76, 19-43, 74-78, 99-101, 115116, 118-119, 123, 125.

115 HR-HDA-215. MDR NDH, dosje Senjske štedionice Senj, Dopis Senjske štedionice upućen 7. studenoga 1942. Državnoj riznici NDH, ur.br. 37.457/1942., kut. br. 305. 
31. prosinca 1942. dobitak štedionice iznosio je 15.548,04 kune, što je s prijenosom dobitka iz protekle godine u vrijednosti od 9.020,77 kuna iznosilo 24.568,81 kunu. ${ }^{116}$

Dugotrajnost i žestina svjetskog rata u 1943. godini odrazila se nepovoljno na sveukupno svjetsko gospodarstvo, a posebice na gospodarstvo ratujućih država, ostavljajući teške posljedice i velike preokrete u gospodarskim prilikama. Naročito je to bilo vidljivo na novčanom tržištu. Takvo teško ratno stanje sa svim poteškoćama osjetilo se i u Nezavisnoj Državi Hrvatskoj. Odrazilo se takvo stanje i na grad Senj, koji je još pretrpio i strahovito bombardiranje iz zraka 7., 8. i 9. listopada 1943. ${ }^{117}$ To je porazno djelovalo na život i stanje Senjana uopće, a napose na rad i poslovanje senjskih privrednika. Sve navedeno negativno je djelovalo i na poslovanje Senjske štedionice, pa se samo upornim nastojanjem njezina ravnateljstva $\mathrm{i}$ činovništva te poslovnih prijatelja uspjelo održati zavod uravnoteženim. Uz ovakve prilike ravnateljstvo štedionice nije pokušalo provesti prihvaćen prijedlog o povišenju dioničke glavnice na 2,500.000 kuna, odnosno za 1,375.000 kuna više. To je ostavljeno za bolja i mirnija vremena. Čisti dobitak u 1943. godini iznosio je 6.497,74 kune, od čega je trebalo dotirati sa $10 \%$ Specijalni fond za rezerve, odnosno sa 649,77 kuna. Tim iznosom trebalo je nabaviti vrijednosne papire, pa je nakon toga ostao čisti dobitak od 5.847,97 kuna. S prijenosom dobitka iz 1942. godine od 22.111,93 kune, ukupni dobitak iznosio je 27.959,90 kuna. Krajem 1943. stanje blagajne iznosilo je 19.171,79 kuna, stanje mjenica 520.719,75 kuna, dužnici po tekućem računu 3,655.872,14 kuna, a stanje uloga 1,992.541,28 kuna. ${ }^{118}$

29. listopada 1944. održana je redovita glavna skupština dioničara Senjske štedionice na kojoj su izabrani članovi uprave. U ravnateljstvo su izabrani dr. Ante Lončarić, Viktor Benzia, Karlo Mladineo, Petar Ostrman, Josip Murković, Vladimir Parac, prof. Petar Šimatić, dr. Ante Vlahović, mr. ph. Jerko Dominis, prof. Jakov Bosnić, Stipe Vukelić i Josip Geržanić. U nadzorni odbor izabrani

${ }^{116}$ Poziv na LXX. redovitu glavnu skupštinu dioničara Senjske štedionice u Senju od 8. srpnja 1943., Narodne novine. Službeni list Nezavisne Države Hrvatske, br. 170, 29. srpnja 1943, 8.

${ }_{117}$ O njemačkom bombardiranju Senja vidi: A. GLAVIČIĆ, 1984, 341-354. Također, vidi: M. SOBOLEVSKI, 2003, 363-376. SOBOLEVSKI, MIHAEL. "BOMBARDIRANJE SENJA ZRAKOPLOVIMA U DRUGOM SVJETSKOM RATU." Senjski zbornik 30, br. 1 (2003): 363-376 GLAVIČIĆ, ANTE. "NJEMAČKO BOMBARDIRANJE SENJA 1943.." Senjski zbornik 10-11, br. 1 (1984): 341-354 GLAVIČIĆ, ANTE. "NJEMAČKO BOMBARDIRANJE SENJA 1943.." Senjski zbornik 10-11, br. 1 (1984): 341-354 GLAVIČIĆ, ANTE. "NJEMAČKO BOMBARDIRANJE SENJA 1943.." Senjski zbornik 10-11, br. 1 (1984): 341-354

${ }^{118}$ HR-HDA-215. MDR NDH, dosje Senjske štedionice Senj, Izvješće ravnateljstva Senjske štedionice za glavnu skupštinu, 25. rujna 1944., ur.br. 20392/1944., kut. br. 305. 
su: prof. Jakov Čanić, Franjo Bezjak, Matija Moguš, Josip Antić i Jakov Pajdaš. Zamjenici članova nadzornog odbora bili su Anton Vrhovac i Vinko Vlahović. ${ }^{119}$ 31. prosinca 1944. razmjera Senjske štedionice bila je sljedeća (u kunama): ${ }^{120}$

Tabl. 9. Razmjera Senjske štedionice 31. prosinca 1944.

\begin{tabular}{|l|r|l|r|}
\hline \multicolumn{2}{|c|}{ Aktiva (imovina) } & \multicolumn{2}{c|}{ Pasiva (dugovina) } \\
\hline Blagajna & $2,811.162,69$ & Dionička glavnica & $1,125.000 .-$ \\
\hline Dužnici u tekućem računu & $2,904.219,47$ & Pričuvna zaklada & $250.000 .-$ \\
\hline Mjenice & $348.228,25$ & Poslovna rezerva & $12.603,91$ \\
\hline Vrijednosni papiri & $42.310,50$ & Vjerovnici po tekućem računu & $3,300.927,91$ \\
\hline Vlastite nekretnine & $470.000 .-$ & Ulozi & $1,877.154,52$ \\
\hline Inventar & $9.184 .-$ & Dobitak & $19.418,57$ \\
\hline Ukupno: & $6,585.104,91$ & Ukupno: & $6,585.104,91$ \\
\hline
\end{tabular}

Na isti dan račun gubitka i dobitka bio je sljedeći (u kunama): ${ }^{121}$

Tabl. 10. Račun gubitka i dobitka Senjske štedionice 31. prosinca 1944.

\begin{tabular}{|l|r|l|r|}
\hline \multicolumn{2}{|c|}{ Rashod } & \multicolumn{2}{c|}{ Prihod } \\
\hline Plaće i dr. & $460.749 .-$ & Razni kamati & $314.597,14$ \\
\hline Reeskontni i povraćeni kamati & $6.390,08$ & Providba & $211.088,94$ \\
\hline Porez, pristojbe i dr. & $42.545,50$ & Razni dohodci & $72.819,73$ \\
\hline Porez na kamate uloga & $3.445,11$ & Prihod vlastitih nekretnina & $22.140 .-$ \\
\hline Kamati od tekućih računa & $18.858,37$ & & \\
\hline Kamati od uloga & $53.676,25$ & & \\
\hline Razni troškovi & $34.981,50$ & & \\
\hline Ukupno: & $620.645,81$ & Ukupno: & $620.645,81$ \\
\hline
\end{tabular}

Nažalost, u dosad pronađenim izvorima i objavljenoj literaturi ne navodi se podatak o poslovanju štedionice do svibnja 1945. Analizom poslovanja štedionice u Nezavisnoj Državi Hrvatskoj vidljivo je da je ona, za razliku od većega broja štedionica koje su poslovale s gubitkom, nastavila s uspješnim poslovanjem te je prebrodila i ratnu krizu. Možemo opet zaključiti da je, s

119 HR-HDA-215. MDR NDH, dosje Senjske štedionice Senj, Zapisnik LXXI. redovite glavne skupštine dioničara Senjske štedionice od 29. listopada 1944., ur.br. 20392/1944., kut. br. 305 .

${ }^{120}$ HR-HDA-620. SLSP CNBJZ, 8.109.2. Upravni poslovi u vezi likvidacije Senjske štedionice, Račun razmjere per 31. prosinca 1944., kut. br. 282.

${ }^{121}$ HR-HDA-620. SLSP CNBJZ, 8.109.2. Upravni poslovi u vezi likvidacije Senjske štedionice, Račun gubitka i dobitka per 31. prosinca 1944., kut. br. 282. 
obzirom na svoju dioničku glavnicu i konstantno poslovanje s dobitkom, Senjska štedionica predstavljala značajniji lokalni novčarski zavod.

\section{Likvidacija Senjske štedionice Senj u socijalističkoj Jugoslaviji}

Nakon završetka Drugoga svjetskoga rata nova jugoslavenska socijalistička vlast pristupila je nacionalizaciji sredstava za proizvodnju, stvaranju državnoga vlasništva te izgradnji administrativno-centralističkog sustava upravljanja društvenim poslovima, naročito privredom. Otpočeo je proces likvidacije svih oblika privatnog vlasništva. Privatni novčarski zavodi stavljeni su prvo pod kontrolu, a zatim je uslijedila njihova likvidacija. ${ }^{122}$

Rješenjem Ministarstva financija Federalne države Hrvatske br. 10.222/94 od 8. listopada 1945. nije dozvoljen nastavak rada Senjske štedionice te je upućena na zatraživanje likvidacije. Na temelju navedenoga rješenja ravnateljstvo štedionice podnijelo je 30. studenoga 1945. Okružnom narodnom sudu na Sušaku molbu za likvidaciju te imenovanje likvidatora. Već prije toga prostorije štedionice zauzeo je Financijski odjel Kotarskog narodnog odbora Senj te je ujedno i zaposlio Nevenku ud. Katalinić, jedinu činovnicu štedionice. Rad je štedionice iz navedenog razloga posve stao, pa je rješenje saveznog Ministarstva financija VII br. 9.271 od 20. studenoga 1945. ${ }^{123}$ izbjeglo evidenciji zavoda tim više što Narodne novine nisu na vrijeme stizale te se time zakasnilo udovoljiti određenim zadacima. ${ }^{124}$

${ }^{122}$ D. BILANDŽIĆ, 1999, 221-231; O. B. GILER, 1982, 137.

${ }_{123}$ Temeljem Rješenja o reviziji dozvola za rad privatnih kreditnih ustanova koje je savezno Ministarstvo financija u Beogradu donijelo 20. studenoga 1945. pod VII br. 9.271, sve privatne kreditne ustanove spomenute u Zakonu o uređenju $i$ djelovanju kreditnog sistema (banke i njihove podružnice, osiguravajuća poduzeća i njihove podružnice, kreditne zadruge po Trgovačkom zakonu, bankarske radnje i slično), bez obzira da li su poslovale ili ne, bile su dužne podnijeti svoju dozvolu za rad saveznom Ministarstvu financija preko nadležnog zemaljskog Ministarstva financija najkasnije do 31. prosinca 1945., radi revizije. Uz dozvolu za rad, ustanove su trebale dostaviti na reviziju: bilancu za 1944. godinu, izvještaj upravnog i nadzornog odbora za 1944. godinu, popis članova upravnog i nadzornog odbora ili članova likvidacijskog odbora, popis glavnih dioničara, popis osoba kojima je posljednji puta isplaćena dividenda te podatke o dioničkoj glavnici. Ukoliko privatne kreditne ustanove nisu podnijele svoju dozvolu za rad na reviziju, temeljem čl. 4. navedenog Rješenja bile su upućene na likvidaciju, a odgovorne osobe kažnjene novčanom kaznom do 500.000 dinara. U težim slučajevima vodio se protiv njih kazneni postupak. Vidi: Narodne novine. Službeni list Federalne Hrvatske, br. 90, 12. prosinca $1945,1$.

${ }^{124}$ HR-HDA-620. SLSP CNBJZ, 8.109.2. Upravni poslovi u vezi likvidacije Senjske štedionice, dopis Senjske štedionice upućen 14. veljače 1946. Financijskom odjelu Okružnog narodnog odbora za Hrvatsko Primorje, kut. br. 282. 
Temeljem navedenog rješenja Ministarstva financija Federalne države Hrvatske od 8. listopada 1945., Okružni narodni sud za Hrvatsko Primorje u Sušaku objavio je 27. prosinca 1945. da je u trgovački registar ovoga suda za društvene tvrtke kod Senjske štedionice u Senju određen upis likvidacije te upis petorice imenovanih likvidatora, koji su po dvojica potpisivali tvrtku. Bili su to Karlo Mladineo, Jakov Čanić, Viktor Benzia, Jerko Dominis i Anton Vrhovac. Istovremeno je određen upis brisanja članova dotadašnjeg ravnateljstva u sastavu dr. Ante Lončarić, Viktor Benzia, Ivica Dragičević, Miroslav Sušić, Filip Krišković, Ivan Špalj i Petar Šimatić. ${ }^{125}$

Likvidatori Senjske štedionice zamolili su 14. veljače 1946. Financijski odjel Okružnog narodnog odbora za Hrvatsko Primorje da, zbog gore navedenih razloga, opravda nenamjerno kašnjenje dozvole za rad i ostalih relevantnih podataka. Ujedno su poslali podatke o poslovanju koje je u rješenju od 20. studenoga 1945. zatražilo savezno Ministarstvo financija. Izvještaj upravnog i nadzornog odbora za 1944. nije se mogao poslati jer nije bio sastavljen. Naime, u to je vrijeme svaki rad bio onemogućen zbog ratnih prilika i čestih napada iz zraka na grad Senj. Prema riječima likvidatora štedionice, dividenda je posljednji put isplaćena prije otprilike 20 godina, a ustanovljenje tih osoba iziskivalo bi mnogo vremena. ${ }^{126}$

Temeljem čl. 31. Zakona o uređenju i djelovanju kreditnog sistema ${ }^{127}$ od 26. listopada 1945. i već navedenoga rješenja saveznog Ministarstva financija od 20. studenoga 1945., Financijski odjel Okružnog narodnog odbora za Hrvatsko Primorje poslao je 22. veljače 1946. Ministarstvu financija NRH u Zagrebu obrazloženje Senjske štedionice u vezi s revizijom dozvole za rad. ${ }^{128}$

${ }^{125}$ Likvidacija, Narodne novine. Službeni list Federalne Hrvatske, br. 10, 12. siječnja 1946, Zagreb, 3. Također, vidi: HR-HDA-620. SLSP CNBJZ, 8.109.2. Upravni poslovi u vezi likvidacije Senjske štedionice, Rješenje Okružnog narodnog suda za Hrvatsko Primorje u Sušaku od 27. prosinca 1945., kut. br. 282.

${ }^{126}$ HR-HDA-620. SLSP CNBJZ, 8.109.2. Upravni poslovi u vezi likvidacije Senjske štedionice, dopis Senjske štedionice upućen 14. veljače 1946. Financijskom odjelu Okružnog narodnog odbora za Hrvatsko Primorje, kut. br. 282.

${ }^{127}$ To je bio prvi zakon u socijalističkoj Jugoslaviji iz područja bankarstva. Zakon je dopuštao i postojanje privatnih kreditnih ustanova. Privatne banke mogle su raditi samo ako su imale dozvolu za rad saveznog ministra financija. To je isto vrijedilo i za njihove podružnice. U čl. 31. navedenog zakona napominje se da se dozvole za rad postojećih privatnih banaka imaju revidirati, s time da se odobri rad samo onim ustanovama koje su mogle korisno poslužiti narodnoj privredi. Vidi: Službeni list Demokratske Federativne Jugoslavije, br. 87, 9. studenoga 1945, 916.

${ }^{128}$ HR-HDA-620. SLSP CNBJZ, 8.109.2. Upravni poslovi u vezi likvidacije Senjske štedionice, Dopis Financijskog odjela Okružnog narodnog odbora za Hrvatsko Primorje br. 714/ VIII-46. upućen 22. veljače 1946. Odjelu za novčarska poduzeća Ministarstva financija NRH u Zagrebu u predmetu revizije dozvole za rad Senjske štedionice, kut. br. 282. 
Ministarstvo financija NRH u Zagrebu dostavilo je 2. ožujka 1946. saveznom Ministarstvu financija u Beogradu podnesak Senjske štedionice radi revizije dozvole za rad. Predložilo je da se odobri već doneseno rješenje toga Ministarstva te da se štedionici ne dozvoli nastavak rada, već odredi likvidacija, kao što je to i sama štedionica zatražila. U vezi s time, a povodom dopisa Ministarstva financija FNRJ VII br. 17.135 od 27. rujna 1946., Ministarstvo financija NRH u Zagrebu predložilo je 5. studenoga 1946. za likvidatore Senjske štedionice Marka Rukavinu, Nevenku Katalinić i Antuna Vrhovca. ${ }^{129}$

Prema podacima Odjela za narodnu imovinu Predsjedništva Vlade Narodne Republike Hrvatske u Zagrebu upućenim 14. svibnja 1946. Državnoj upravi narodnih dobara u Beogradu, Senjska štedionica u likvidaciji imala je dioničku glavnicu od predratnih 1,125.000 dinara koja je bila podijeljena na 22.500 dionica. Dostavljen je i popis dioničara štedionice koji su bili poznati samom zavodu, i to: dr. Ante Lončarić (Senj), Viktor Benzia (Senj/Sv. Juraj), Petar Šimatić (Senj), Stjepan Dragičević (Senj), Bruno Franceschini (Zadar), Milan Brajković (Senj), Karlo Mladineo (Senj), Biskupski ordinarijat (Senj) (vlasništvo Martina-Davorina Krmpotića, Kansas City), Marinka Gražanić1 ${ }^{130}$ (Senj), Petar Ostrman (Senj), dr. Vilko Tauzani (Delnice), Eugen Scarpa (Senj), Josip Murković (Stajnica/Zagreb), Vladimir Parac (Brinje), Juraj Biondić (Senj), Ivan Špalj (Senj), Juraj B. Tićak (Zagreb), Romeo Bezjak (Senj), Društvo Sv. Jurja (Senj), dr. Antun Vlahović (Senj), Miroslav Sučić ${ }^{131}$ (Zagreb), Drago Ratković (Zagreb), Milan Marjanović (Zagreb), mr. ph. Nikola Rukavina (Senj), Vale Rukavina (Senj), Milan Ratković (Zagreb), Olga Erić (Zagreb), prof. Jakov Čanić (Senj), Vladimir-Slave Olivieri (Senj), Josip Stanišić (Senj), Marko Katalinić (Novi Vinodol/Plovile), Tomo Vukušić (Senj), Konrad Nabršnigg (Senj), Tomo Krmpotić (Senj/Beograd), Cvjeta Juhn (Zagreb), Vilko Horvat (Koprivnica), Vinko Vlahović (Senj), Vičevićeva zaklada $^{132}$, Božo Katalinić (Otočac), Stjepan Šojat (Senj), prof. Jakov Bosnić (Senj), mr. ph. Jerko Dominis (Senj), Nikola Katalinić (Senj), Franjo Bezjak (Senj), Matija Moguš (Senj), Stipe Vukelić (Senj), Jakov Pajdaš (Senj), Josip

${ }^{129}$ HR-HDA-620. SLSP CNBJZ, 8.109.2. Upravni poslovi u vezi likvidacije Senjske štedionice, Dopis Odjela za kreditne ustanove Ministarstva financija NRH u Zagrebu br. 18.06846. upućen 2. ožujka 1946. Bankovno-valutnom odjeljenju saveznog Ministarstva financija u Beogradu u predmetu revizije dozvole za rad Senjske štedionice; Dopis Odjela za kreditne ustanove Ministarstva financija NRH u Zagrebu br. 3.049-VI-1946. upućen 5. studenoga 1946. Bankovno-valutnom odjeljenju Ministarstva financija FNRJ u Beogradu u predmetu prijedloga za postavljanje likvidacijskih organa Senjske štedionice, kut. br. 282.

${ }^{130} \mathrm{U}$ dokumentima se spominje i kao Marinka Geržanić, što i jest ispravno.

${ }^{131}$ U dokumentima se spominje i kao Miroslav Sušić.

${ }^{132} \mathrm{U}$ dokumentima se spominje i kao Vičićeva zaklada. 
Zorko (Senj), mr. ph. Oskar Vičević (Ogulin), Anton Vrhovac (Senj), Josip Antić (Senj), Vjekoslav Antić (Senj), Drago Vlahović (Zagreb), Franjo Šojat (Senj), Ivan Mihovilić (Senj), Milan Šojat (Senj), Juraj Brlečić (Senj), Zvonko Prpić (Senj), dr. Nikola Zdunić (Ogulin), Danica Dujmović (Retfala/Slavonija), Adolf Krajač (Senj), Josip Smetana (Senj), dr. Lovro Vidrić, Krsto Vuković (Jezerane/Zagreb) i Filip Krišković (Senj/Zagreb). Od navedenih dioničara, konfiscirana je imovina dr. Anti Lončariću, Milanu Brajkoviću, Juraju Biondiću, dr. Antunu Vlahoviću, Miroslavu Sučiću, Vinku Vlahoviću, Matiji Mogušu, Dragi Vlahoviću, Ivanu Mihoviliću i Krsti Vukoviću. ${ }^{133}$

Rješenjem Ministarstva financija FNRJ VII br. 19.973 od 13. studenoga 1946. određena je likvidacija Senjske štedionice u Senju te je postavljen likvidacijski odbor sastavljen od triju članova. ${ }^{134}$

Okružni narodni sud u Sušaku objavio je 9. prosinca 1946. da je u trgovačkom registru ovoga suda upisana likvidacija Senjske štedionice Senj kao i upis postavljenog likvidacijskog odbora, u sastavu: 1. Marko Rukovina kao predsjednik i predstavnik Ministarstva financija FNRJ, 2. Nevenka Katalinić, bivša činovnica štedionice kao član i predstavnik Senjske štedionice te 3. Antun Vrhovac iz Senja kao član i zastupnik ulagača štedionice. ${ }^{135}$

20. prosinca 1946. Ministarstvo financija NRH obavijestilo je Ministarstvo financija FNRJ u Beogradu da ih je 6. prosinca 1946. Kotarski narodni odbor u Senju izvijestio da je Nevenka Katalinić otišla s područja toga kotara. Stoga je predloženo da se za predstavnika Senjske štedionice umjesto nje imenuje Vinko Švob, činovnik Zemaljske banke za Hrvatsku Središnjice Narodne banke FNRJ za NRH, podružnice u Senju. Ministarstvo financija FNRJ odobrilo je tu promjenu 30. prosinca 1946., a Okružni narodni sud u Sušaku upisao ju je 6. veljače 1947. u trgovački registar. ${ }^{136}$

${ }^{133}$ HR-HDA-313. Zemaljska uprava narodnih dobara Narodne Republike Hrvatske (Zemaljska uprava narodnih dobara Federalne Hrvatske 1945. - 1946., Zemaljska uprava narodnih dobara NRH 1946. - 1954.) - Zagreb (1945. - 1954.), dosje Senjske štedionice Senj br. 334, ur.br. 8213/1946., kut. br. 437. U vezi s konfisciranjem imovine, u dokumentima se spominje još i Josip Murković.

${ }^{134}$ HR-HDA-620. SLSP CNBJZ, 8.109.2. Upravni poslovi u vezi likvidacije Senjske štedionice, Rješenje Bankovnog odjeljenja Ministarstva financija NRH br. 11.104-I-1-1948. od 2. srpnja 1948., kut. br. 282.

${ }^{135}$ Likvidacije, Narodne novine. Službeni list Narodne Republike Hrvatske, br. 150, 27. prosinca 1946., VIII.

136 HR-HDA-620. SLSP CNBJZ, 8.109.2. Upravni poslovi u vezi likvidacije Senjske štedionice, dopis Odjela za kreditne ustanove Ministarstva financija NRH br. 4.398-VI-1946. upućen 20. prosinca 1946. Bankovno-valutnom odjeljenju Ministarstva financija FNRJ u Beogradu; dopis Odjela za kreditne ustanove Ministarstva financija NRH br. 855-VII-1947. upućen 13. veljače 1947. Bankovno-valutnom odjeljenju Ministarstva financija FNRJ u Beogradu, kut. br. 282. 
Budući da likvidacijsko tijelo privatnih kreditnih ustanova u likvidaciji nije uspjelo provesti likvidaciju do isteka roka u kojem je trebalo izvršiti, temeljem Rješenja o preuzimanju aktivei pasive privatnih kreditnih poduzeća u likvidaciji od 9. svibnja 1948. država je preuzela cjelokupnu aktivu i pasivu Senjske štedionice Senj prema odobrenoj završnoj likvidacijskoj bilanci. Završnu likvidacijsku bilancu likvidator je trebao dostaviti na odobrenje Ministarstvu financija NRH u roku od 3 mjeseca od dana objave ovoga Rješenja. Preuzimanjem cjelokupne aktive država je istodobno preuzela i namirenje svih obveza navedene privatne kreditne ustanove u likvidaciji, a u granicama vrijednosti preuzete aktive. Daljnji postupak likvidacije Senjske štedionice trebao se provesti po propisima čl. 19.26. Pravilnika o postupku likvidacije privatnih kreditnih poduzeća (pročišćeni tekst) ${ }^{137}$ od 16. prosinca 1947. godine. ${ }^{138}$

Rješenjem o razrješenju likvidacionih organa i imenovanju likvidatora kod privatnih kreditnih poduzeća u likvidaciji od 14. lipnja 1948., razriješena su dužnosti likvidacijska tijela Senjske štedionice, a za likvidatora je postavljena Narodna banka FNRJ - Centrala za NR Hrvatsku. Razriješeni likvidacijski odbori trebali su odmah predati cjelokupno poslovanje novopostavljenomu likvidatoru. ${ }^{139}$

$\mathrm{Na}$ temelju čl. 21. Pravilnika o postupku likvidacije privatnih kreditnih poduzeća (pročišćeni tekst), ${ }^{140}$ Ministarstvo financija NRH odobrilo je 23. lipnja 1948. po Narodnoj banci FNRJ - Centrali za NR Hrvatsku, kao likvidatoru, predloženu završnu likvidacijsku bilancu Senjske štedionice za 21. lipnja 1948. sa sljedećim stanjem: ${ }^{141}$

${ }_{137}$ Čl. 19.-26. Pravilnika o postupku likvidacije privatnih kreditnih poduzeća (pročišćeni tekst) od 16. prosinca 1947. propisuju postupak likvidacije po čl. 10. Uredbe o drugoj izmjeni i dopuni Uredbe o reviziji dozvola za rad i likvidaciji privatnih kreditnih poduzeća. Vidi: Službeni list Federativne Narodne Republike Jugoslavije, br. 3, 10. siječnja 1948, 31-33. Temeljem čl. 10. navedene Uredbe, u slučaju ako likvidator nije uspio provesti likvidaciju do isteka roka u kojem ju je trebao završiti, ministar financija narodne republike trebao je donijeti rješenje da cjelokupnu aktivu i pasivu privatnog kreditnog zavoda u likvidaciji, prema odobrenoj završnoj likvidacijskoj bilanci, preuzme država. Vidi: Službeni list Federativne Narodne Republike Jugoslavije, br. 96, 12. studenoga 1947., 1348.

${ }^{138}$ Narodne novine. Službeni list Narodne Republike Hrvatske, br. 39, 15. svibnja 1948., 104.

${ }^{139}$ Narodne novine. Službeni list Narodne Republike Hrvatske, br. 48, 16. lipnja 1948., 1.

140 Temeljem čl. 21. Pravilnika o postupku likvidacije privatnih kreditnih poduzeća (pročišćeni tekst) od 16. prosinca 1947., ako se ministar financija dotične narodne republike složio sa završnom likvidacijskom bilancom, odobrio je da se provede predložena likvidacija. Vidi: Službeni list Federativne Narodne Republike Jugoslavije, br. 3, 10. siječnja 1948., 32.

${ }^{141}$ HR-HDA-620. SLSP CNBJZ, 8.109.2. Upravni poslovi u vezi likvidacije Senjske štedionice, spis Ministarstva financija NRH (Opće odjeljenje-Kreditne ustanove) br. 10.246-I-11948. od 23. lipnja 1948., kut. br. 282. 
Tabl. 11. Završna likvidacijska bilanca Senjske štedionice 21. lipnja 1948.

\begin{tabular}{|l|r|l|r|}
\hline \multicolumn{2}{|c|}{ Aktiva (u dinarima) ${ }^{142}$} & \multicolumn{2}{c|}{ Pasiva (u dinarima) } \\
\hline Račun kod Narodne banke & $118.375 .-$ & Troškovi likvidacije & $11.744 .-$ \\
\hline Nekretnine & $510.000 .-$ & $\begin{array}{l}\text { Javne daće: } \\
\text { a) porez (181.373.-) } \\
\text { b) račun razlike (347.351.-) }\end{array}$ & $528.724 .-$ \\
\hline & & $\begin{array}{l}\text { Ulagači po uložnim knjižicama } \\
\text { do 5.000 dinara sa 100\% }\end{array}$ & $87.907 .-$ \\
\hline Ukupno: & $628,375 .-$ & Ukupno: & $628,375 .-$ \\
\hline
\end{tabular}

Prema gornjoj odobrenoj završnoj likvidacijskoj bilanci, iz imovine likvidirane banke trebali su se podmiriti troškovi likvidacije, javne daće i ulagači po uložnim knjižicama do 5.000 dinara u cijelosti (100\%). Ostali ulagači i vjerovnici te dioničari uopće nisu bili podmireni jer za to nije dostajala imovina likvidirane štedionice. Nakon što je cjelokupnu aktivu i pasivu preuzela država u smislu čl. 10. Uredbe o drugoj izmjeni i dopuni Uredbe o reviziji dozvola za rad i likvidaciji privatnih kreditnih poduzeća, u svrhu završetka likvidacije Narodna banka FNRJ-Centrala za NRH u Zagrebu kao likvidator Senjske štedionice trebala je provesti sljedeće: 1. preuzeti potraživanje likvidirane štedionice prema filijali Narodne banke u Senju u iznosu od 118.375 dinara; 2. predati nekretnine na upravljanje Mjesnom narodnom odboru Senj; 3. podmiriti dotad nastale troškove likvidacije u granicama iznosa od 11.744 dinara, a po obračunu koji je dostavio dotadašnji likvidacijski odbor. Ostatak je trebalo predvidjeti za

${ }^{142}$ Zakonom o povlačenju i zamjeni okupacijskih novčanica od 5. travnja 1945. uvodi se nova novčana jedinica Demokratske Federativne Jugoslavije - dinar (din), koji se dijelio na 100 para (p). Na teritoriju DFJ povlače se iz opticaja dotadašnje novčanice: albanski franak (leka), talijanska lira, kune, levi, njemačke marke, penge i tzv. srpski dinar (Nedićev) i zamjenjuju se za novčanice dinara DFJ. Zakonom o tečajevima za povlačenje okupacijskih novčanica i o uređenju obveza na području Hrvatske od 21. lipnja 1945. odredila se zamjena za dinare DFJ. Zamjena novčanica obavila se u vremenu od 30. lipnja do 9. srpnja 1945. i to po sljedećem tečaju: 1.000 kuna $=7$ dinara DFJ. Kao primjer usporedbe vrijednosti dinara DFJ u odnosu na druge valute, navodim privremeni tečaj od 11. prosinca 1945.: 1 američki dolar $=50$ din, 1 kanadski dolar $=50$ din, 1 engleska funta $=200$ din, 1 rubalj SSSR $=5$ din, 1 švicarski franak $=10,70$ din, 1 francuski franak $=0,25$ din. Vidi: S. LAJNERT, 2015, 166. Da bi smo shvatili realnu vrijednost dinara te je usporedili sa stvarnom vrijednošću kapitala štedionice, spomenimo da su na tjednom zagrebačkom sajmu održanom 18. srpnja 1945. cijene bile sljedeće: sijeno 9-11 dinara po kg, slama 7 dinara po kg, ogrjev 750-1.200 dinara po metru, buče 10 dinara, krumpir 12 dinara, luk 10 dinara, jabuke 12 dinara, kruške 18 dinara, mlijeko 12 dinara. Vidi: Gospodarski list, br. 2, 1. kolovoza 1945., 24. U kolovozu 1945. održavani su stočni sajmovi na Banovini. Cijene teladi kretale su se od 1.0001.800 dinara po komadu, a junica i krava od 5.000-8.000 dinara po komadu. Cijena dvogodišnje ždrebadi iznosila je od 4.000-8.000 dinara po komadu, a konja i kobila od 6.000-10.000 dinara po komadu. Vidi Gospodarski list, br. 4, 1. rujna 1945., 23. 
podmirenje budućih troškova. Na teret iznosa troškova (11.744 dinara) trebalo je isplatiti nagradu likvidacijskom odboru od 10.000 dinara; 4. platiti na račun poreza Financijskom odjelu Kotarskog Narodnog odbora Senj iznos od 18.724 dinara, koliko je ostalo slobodne gotovine. Ostatak do daljnjega nije trebalo platiti. Također, do daljnjega nije trebalo platiti iznos računa razlike u vezi sa zamjenom novca u visini od 347.351 dinara; 5. izdati ulagačima po uložnim knjižicama do 5.000 dinara u zamjenu uložne knjižice Narodne banke FNRJ u smislu čl. 22. toč. 2. Pravilnika o postupku likvidacije privatnih kreditnih poduzeća (pročišćeni tekst). ${ }^{143}$ Podnositelj uložne knjižice, koja nije glasila na njega, morao je dokazati svoje vlasništvo. Svaki ulagač je morao, prilikom predaje uložne knjižice u svrhu zamjene, dati pismenu izjavu da protiv njega nije vođen niti se vodio konfiskacijski odnosno sekvestracijski postupak i da njegova imovina nije nacionalizirana; 6 . preuzeti otpisana i dubiozna potraživanja sa svim odnosnim ispravama te ih unovčiti. Polučene iznose trebalo je odobriti tekućem računu Ministarstva financija FNRJ; 7. Ako su postojali neutralni poslovi (polozi i sl.), trebalo ih je predati filijali Državne investicione banke u Zagrebu u polog na ime korisnika; 8. Narodna banka FNRJ-Centrala za NRH kod sebe je trebala zadržati poseban arhiv te o tome izvijestiti Okružni narodni sud u Senju, u smislu čl. 31. Pravilnika o postupku likvidacije privatnih kreditnih poduzeća (pročišćeni tekst) ${ }^{144}$; 9. oglasiti u Narodnim novinama da je likvidacija štedionice završena te način podmirenja ulagača po uložnim knjižicama do 5.000 dinara.

${ }^{143}$ Temeljem čl. 22. toč. 2. Pravilnika o postupku likvidacije privatnih kreditnih poduzeća (pročišćeni tekst) od 16. prosinca 1947., iznimno su tražbine po ulozima na štednju prenesene na Narodnu banku FNRJ u iznosima utvrđenim u završnoj likvidacijskoj bilanci. Narodna banka izdala je ulagačima uložne knjižice pod istim uvjetima koji su bili ugovoreni s kreditnim poduzećem u likvidaciji, a u granicama postojećih propisa. Ulozi preneseni na Narodnu banku FNRJ izjednačeni su u potpunosti s ostalim ulozima kod Narodne banke FNRJ. Narodna banka izdala je ulagaču svoju uložnu knjižicu tek nakon što joj je on predao uložnu knjižicu bivšeg privatnoga kreditnog poduzeća odnosno sudsku odluku o poništenju te uložne knjižice. Za obvezu Narodne banke prema ulagaču bio je mjerodavan iznos u iskazu kojim je Narodna banka preuzela uloge. Gotovina koja je otpadala na prenesene uloge položena je Narodnoj banci FNRJ, a za razliku između položene gotovine i prenesenih uloga Narodna banka FNRJ zadužila je tekući račun Ministarstva financija FNRJ. Vidi: Službeni list Federativne Narodne Republike Jugoslavije, br. 3, 10. siječnja 1948., 32.

144 Temeljem čl. 31. Pravilnika o postupku likvidacije privatnih kreditnih poduzeća (pročišćeni tekst) od 16. prosinca 1947., po završetku svih poslova likvidacije po propisima Uredbe o reviziji dozvola za rad i likvidaciji privatnih kreditnih poduzeća i ovog Pravilnika, likvidator je proveo likvidaciju kroz knjige. Sve spise i knjige kreditnog poduzeća likvidator je stavio na sigurno mjesto koje je odredio nadležni sud i one su trebale biti čuvane deset godina. Po obavljenim navedenim poslovima likvidator je dostavio izvještaj s obračunom ministru financija dotične narodne republike, koji mu je onda izdao razrješnicu. Vidi: Službeni list Federativne Narodne Republike Jugoslavije, br. 3, 10. siječnja 1948., 34. 
Ministarstvo financija NRH upozorilo je Narodnu banku da sve navedeno izvrše odmah, a potom da im dostavi izvještaj o završenoj likvidaciji najkasnije do 3. srpnja 1948. godine, kako bi se moglo odmah obrisati štedionicu iz trgovačkog registra.

Narodna banka FNRJ, Centrala za NRH Zagreb, kao likvidator objavljuje 29. lipnja 1948. da je završena likvidacija Senjske štedionice u likvidaciji po propisima Pravilnika o postupku likvidacije privatnih kreditnih poduzeća (pročišćeni tekst). U skladu sa već navedenom završnom likvidacijskom bilancom Senjske štedionice od 21. lipnja 1948., potvrđene 23. lipnja 1948. po Ministarstvu financija NRH, pozvani su svi ulagači po uložnim knjižicama do 5.000 dinara, da uložne knjižice Senjske štedionice predaju filijali Narodne banke FNRJ u Senju, radi zamjene za uložne knjižice Narodne banke FNRJ počevši od 20. kolovoza 1948. godine. ${ }^{145}$

Rješenjem Ministarstva financija NRH br. 11.104-I-1-1948. od 2. srpnja 1948., nakon završene likvidacije Senjske štedionice, Narodna banka FNRJCentrala za NRH razriješena je dužnosti likvidatora te je predloženo Okružnom narodnom sudu na Sušaku brisanje štedionice iz trgovačkog registra. Isto tako, arhiv i knjige spomenute štedionice pohranjeni su kod Narodne banke FNRJCentrale za NRH u Zagrebu. ${ }^{146}$

Prema Iskazu banaka u likvidaciji s teritorija NR Hrvatske, čija se likvidacija vodila u Službi likvidacije starih poslova Narodne banke Hrvatske, u Hrvatskoj je likvidirano ukupno 130 banaka i štedionica. One su podijeljene u šest grupa, $\mathrm{i}$ to: ${ }^{147}$

1. Nekonfiscirane banke likvidirane po Uredbi o likvidaciji privatnih kreditnih poduzeća (SL FNRJ 51/1946. i 96/1947.) (59).

2. Konfiscirane banke likvidirane po Uredbi o likvidaciji odnosa nastalih konfiskacijom imovine privatnih kreditnih poduzeća (SL FNRJ 19/1949.) (24).

3. Banke likvidirane poslije oslobođenja a prije donošenja Uredbe o likvidaciji privatnih kreditnih poduzeća (SL FNRJ 96/1947.) (32).

${ }^{145}$ Narodne novine. Službeni list Narodne Republike Hrvatske, br. 56, 14. srpnja 1948., III.

${ }^{146}$ HR-HDA-620. SLSP CNBJZ, 8.109.2. Upravni poslovi u vezi likvidacije Senjske štedionice, Rješenje Bankovnog odjeljenja Ministarstva financija NRH br. 11.104-I-1-1948. od 2. srpnja 1948., kut. br. 282.

${ }^{147}$ HR-HDA-620. SLSP CNBJZ, 7.4.1. Iskazi o poslovima i stanju likvidacije privatnih novčarskih zavoda na području NRH, Iskaz banaka u likvidaciji sa teritorija NR Hrvatske, kojih se likvidacija vodi u Službi likvidacije starih poslova, Zagreb, 1960./1976., kut. br. 77. Također, vidi: S. LAJNERT, 2018, 11. 
4. Posebno rješenje za likvidaciju (1).

5. Talijanske banke s okupiranog teritorija (4).

6. Talijanske banke s pripojenog teritorija (10).

Senjska štedionica Senj spadala je u prvu grupu - nekonfiscirane banke likvidirane po Uredbi o likvidaciji privatnih kreditnih poduzeća.

\section{Zaključak}

Cilj ovoga rada prikazje ustroja, poslovanja i likvidacije Senjske štedionice Senj (1873. - 1948.) s aspekta povijesti institucija. Struktura bankovnonovčarskoga sustava (banke, štedionice, zadruge i osiguravajuća društva) u Hrvatskoj i Slavoniji temeljila se na Trgovačkom zakonu od 16. svibnja 1875. i Obrtnom zakonu od 18. svibnja 1884. Obrtni zakon promijenjen je 5. studenoga 1931. donošenjem Zakona o radnjama. U skladu s navedenim zakonima, poslove štedionice obavljali su glavna skupština dioničara, ravnateljstvo i nadzorni odbor. Također, štedionica je imala i svojega stručnog poslovođu. Usprkos velikim ekonomskim krizama, dvama svjetskim ratovima te bombardiranju grada Senja, štedionica je tijekom svojega poslovanja izbjegla sudbinu većine novčarskih zavoda koji su poslovali s gubitkom. S obzirom na svoju dioničku glavnicu i konstantno poslovanje s nekim dobitkom, Senjska štedionica predstavljala je značajniji lokalni novčarski zavod.

Kao i svi privatni novčarski zavodi, Senjska štedionica likvidirana je u socijalističkoj Jugoslaviji. Možemo zaključiti da je Senjsku štedionicu u socijalističkoj Jugoslaviji, bez obzira za njezino dotadašnje poslovanje, stigla sudbina svih privatnih novčarskih zavoda. Naime, jugoslavensko se vodstvo, gradeći novo, socijalističko uređenje, odlučilo za državno vlasništvo i centralizaciju svih političkih, privrednih i društvenih funkcija te se njezina likvidacija jednostavno nije mogla izbjeći. Članak se temelji prvenstveno na proučavanju relevantnoga arhivskoga gradiva koje se nalazi u Hrvatskom državnom arhivu, službenim glasilima i shematizmima te predmetnoj znanstvenoj i stručnoj literaturi. Za nadopunu ovdje iznesenih podataka upućujem zainteresirane na austrijske i mađarske Compasse te na tadašnje dnevne tiskovine, posebice lokalnoga karaktera. Naime, godišnji podaci o poslovanju (bilance, dionički kapital i sl.) i tijelima uprave svih novčarskih zavoda u periodu AustroUgarske Monarhije, Kraljevine SHS/Jugoslavije i Nezavisne Države Hrvatske objavljivani su u Compassima. Same godišnje bilance novčarskih zavoda, kao prilog pozivu na godišnje skupštine dioničara, objavljivane su i u zagrebačkim Narodnim novinama. 
Izvori i literatura

I. Arhivski izvori

Hrvatski državni arhiv (HR-HDA) 79. Zemaljska vlada. Odjel za unutarnje posloveZagreb (1869. - 1921.)

HR-HDA-82. Zemaljska vlada. Odjel za narodno gospodarstvo-Zagreb (1896. - 1923.), Poslovi aprovizacije (X)

HR-HDA-152. Savska financijska direkcija-Zagreb (1929. - 1939.)

HR-HDA-215. Ministarstvo državne riznice Nezavisne Države Hrvatske-Zagreb (1941. -1945$.

HR-HDA-313. Zemaljska uprava narodnih dobara Narodne Republike Hrvatske (Zemaljska uprava narodnih dobara Federalne Hrvatske 1945. - 1946., Zemaljska uprava narodnih dobara NRH 1946. - 1954.)-Zagreb (1945. - 1954.)

HR-HDA-620. Služba likvidacije starih poslova centrale Narodne banke Jugoslavije u Zagrebu (1946. - 1972.)

II. Pravni izvori

Compass, Finanzielles Jahrbuch für Oesterreich-Ungarn 1877, X, Wien, 1877.

Compass, Finanzielles Jahrbuch für Oesterreich-Ungarn 1883, XVI, Wien, 1883.

Compass, Finanzielles Jahrbuch Tschechoslovakei-Jugoslavien 1922, LV, II. Band, Wien, 1922.

Compass, Finanzielles Jahrbuch Jugoslavien-Ungarn 1923, LVI, III. Band, Wien, 1923.

Compass, Finanzielles Jahrbuch Jugoslavien 1928, LXI, Zagreb, 1928.

Compass, Finanzielles Jahrbuch Jugoslavien 1929, LXII, Wien, 1929.

Compass, Finanzielles Jahrbuch Jugoslavien 1931, LXIV, Wien, 1931.

Compass, Finanzielles Jahrbuch Kroatien-Serbien 1943, 76, Wien, 1943.

Gospodarski list, Zagreb, 1942.

Gospodarski list, Zagreb, 1945.

Hrvatski kompas, financijalni ljetopis za 1913./14. o poslovanju privrednih institucija: banaka, štedionica, zadruga, industrialnih, parobrodarskih $i$ inih trgovačkih poduzeća u Hrvatskoj, Slavoniji, Dalmaciji, Istri, Kranjskoj, Koruškoj, Štajerskoj, Bosni i Hercegovini, uz dodatak nekih novčanih zavoda u Ugarskoj, Srbiji i Crnoj Gori, Zagreb, 1913.

Izvještaj o poslovanju Trgovačke i obrtničke komore u Zagrebu u ratnoj godini 1918. do proglašenja nezavisnosti Države SHS, Zagreb, 1918.

Izvještaj Upravnog odbora i kr. podžupana županije Ličko-krbavske od 1. siječnja do 31. prosinca 1917, Gospić, 1919.

Mihók'scher Ungarischer Compass, 1900./1901, Financielles und Commercielles Jahrbuch, I. Theil: Banken und Sparcassen in Oesterreich-Ungarn, XXVIII, Budapest, 1900.

Narodne novine, Zagreb 
Narodne novine. Službeni list Banovine Hrvatske, Zagreb

Narodne novine. Službeni list Federalne Hrvatske, Zagreb

Narodne novine. Službeni list Kraljevske banske uprave Savske banovine, Zagreb

Narodne novine. Službeni list Narodne Republike Hrvatske, Zagreb

Narodne novine. Službeni list Nezavisne Države Hrvatske, Zagreb

Narodne novine. Službeni list Savske banovine

Sbornik zakonah i naredabah valjanih za kraljevinu Hrvatsku i Slavoniju, godina 1875, Zagreb, 1876.

Sbornik zakonah i naredabah valjanih za kraljevinu Hrvatsku i Slavoniju, godina 1877, Zagreb, 1878.

Sbornik zakonah i naredabah valjanih za kraljevine Hrvatsku i Slavoniju, godina 1884, Zagreb, 1884.

Sbornik zakonah i naredabah valjanih za Kraljevine Hrvatsku i Slavoniju, godina 1899, Zagreb, 1899.

Službene novine Kraljevine Srba, Hrvata i Slovenaca, Beograd

Službene novine Kraljevine Jugoslavije, Beograd

Službeni list Demokratske Federativne Jugoslavije, Beograd

Službeni list Federativne Narodne Republike Jugoslavije, Beograd

Ungarischer Compass 1916.-1917, Financielles und Commercielles Jahrbuch, I. Teil: Geld und Creditinstitute, XLIV, Band I, Budapest, 1916.

Zemaljsko vladni list za kraljevine Hérvatsku i Slavoniju, godina 1857., I. razdiel, II. svezak, Zagreb, 1857.

\section{Knjige i članci}

Mato ARTUKOVIĆ, Izidor Kršnjavi kao brodski zastupnik u Hrvatskom saboru 1884. 1887., Scrinia Slavonica, 6, Slavonski Brod, 2006, 217-233.

Dušan BILANDŽIĆ, Hrvatska moderna povijest, Zagreb, 1999.

Ivan BRLIĆ, Lička i senjska građanska društva 1835. - 1945., Zagreb, 2017.

Ante GLAVIČIĆ, Njemačko bombardiranje Senja 1943., Senjski zbornik, 10-11, Senj, 1984, 341-354.

Ante GLAVIČIĆ, Iz prošlosti Hrvatskog Sokola u Senju uz 105. obljetnicu osnutka društva prema prikazu dr. Ante Vlahovića, Senjski zbornik, 21, Senj, 1994, 239252.

Bratoljub KLAIĆ, Rječnik stranih riječi, tuđice i posuđenice, Zagreb, 2001.

Josip KOLANOVIĆ (ur.), Arhivski fondovi i zbirke u arhivima i arhivskim odjelima $u$ SFRJ: SR Hrvatska, Beograd, 1984.

Mira KOLAR, Senjanin Josip Gržanić, pravaški političar, u obnovi Senja i Hrvatske, Senjski zbornik, 22, Senj, 1995, 267-292.

Mira KOLAR, Senjski gospodarstvenik i političar Drago Vlahović, Senjski zbornik, 24, Senj, 1997, 151-168. 
Mira KOLAR-DIMITRIJEVIĆ, Povijest novca u Hrvatskoj od 1527. do 1941. godine, Zagreb, 2013.

Olga B. GILER, Formiranje arhivskog fonda na nivou federacije iz oblasti bankarstva, Arhivist, 32, br. 1-2, Beograd, 1982, 132-160.

Siniša LAJNERT, Arhivistički prikaz sustava bankovno-novčarskih institucija u Hrvatskoj do likvidacije privatnih kreditnih poduzeća (1846. - 1949.), (doktorski rad), Zagreb, 2008.

Siniša LAJNERT, Jastrebarska dionička štedionica u Jastrebarskom: ustroj, djelovanje i likvidacija (1894.-1948.), Arhivski vjesnik, 58, Zagreb, 2015, 121-174.

Siniša LAJNERT, Sumarni inventar za fond HR-HDA-620. Služba likvidacije starih poslova centrale Narodne banke Jugoslavije u Zagrebu (1946. - 1972.), Zagreb, 2018 .

Mihael SOBOLEVSKI, Bombardiranje Senja zrakoplovima u Drugom svjetskom ratu, Senjski zbornik, 30, Senj, 2003, 363-376.

Krešimir ŠKULJEVIĆ, Biskup Vjenceslav Soić: žrtva borbe za opstanak Senja kao vjerskog i obrazovnog središta, Senjski zbornik, 39, Senj, 2012, 95-112.

Jozo TOMAŠEVIĆ, Novac i kredit, Zagreb, 1938.

Đuro VANĐURA, Zbirka umjetnina Arthuta grofa Nugenta na Trsatu, Peristil, 34, Zagreb, 1991, 131-136.

\section{THE SENJ SAVINGS BANK (1873 - 1948)}

\section{Summary}

In the article, the author, from the aspect of the history of the institution, deals with the business and liquidation of the Senj savings bank from 1873, when the savings bank was founded, all the way to 1948, when its liquidation was completed. The business affairs of the savings bank were carried out by a main assembly of shareholders, a directorate and supervisory board. Despite the large economic crises and two world wars, Senj's savings bank avoided the fate of the majority the financial institutions that operated with a loss. It was one of the rare institutions which never had any kind safeguards nor was it ever appointed with a commissioner. The directorate of the savings bank always began from the standpoint that the institution should primarily be preserved, which is what it succeeded in. With the sturdy determination of its directorate and clerical service and business friends, the savings bank overcame all crises, generally with ease, if only with a modest profit. The directorate adapted its work to the circumstances and faithfully to its principles, in order for the savings bank to better serve the business world and successfully preserve the gained trust of its business friends.

Immediately after World War Two, the work of the savings bank completely stopped. Given that there was not one condition for the further successful work of the Senj savings bank and given the planned liquidation of private financial institutions, in socialist Yugoslavia, the liquidation of institutions was specified as early as 1945, and it was completed in 1948.

Keywords: Senj savings bank, financial institution, savings bank business affairs, shareholders, balance sheets, liquidation, 1873 - 1948 